\title{
Air pollution and associated human mortality: the role of air pollutant emissions, climate change and methane concentration increases from the preindustrial period to present
}

\author{
Y. Fang ${ }^{1, *}$, V. Naik ${ }^{2}$, L. W. Horowitz ${ }^{3}$, and D. L. Mauzerall ${ }^{1,4}$ \\ ${ }^{1}$ Program in Science, Technology and Environmental Policy, Woodrow Wilson School of Public and International Affairs, \\ Princeton University, Princeton, NJ, 08544, USA \\ ${ }^{2}$ UCAR/Geophysical Fluid Dynamics Laboratory, Princeton, NJ, 08540, USA \\ ${ }^{3}$ NOAA Geophysical Fluid Dynamics Laboratory, Princeton, NJ, 08540, USA \\ ${ }^{4}$ Department of Civil and Environmental Engineering, Princeton University, Princeton, NJ, 08544, USA \\ *now at: Department of Global Ecology, Carnegie Institution for Science, Stanford, CA 94305, USA
}

Correspondence to: D. L. Mauzerall (mauzeral@princeton.edu) and Y. Fang (yyfang@stanford.edu)

Received: 28 July 2012 - Published in Atmos. Chem. Phys. Discuss.: 3 September 2012

Revised: 21 January 2013 - Accepted: 22 January 2013 - Published: 4 February 2013

\begin{abstract}
Increases in surface ozone $\left(\mathrm{O}_{3}\right)$ and fine particulate matter $\left(\leq 2.5 \mu \mathrm{m}\right.$ aerodynamic diameter, $\left.\mathrm{PM}_{2.5}\right)$ are associated with excess premature human mortalities. We estimate changes in surface $\mathrm{O}_{3}$ and $\mathrm{PM}_{2.5}$ from pre-industrial (1860) to present (2000) and the global present-day (2000) premature human mortalities associated with these changes. We extend previous work to differentiate the contribution of changes in three factors: emissions of short-lived air pollutants, climate change, and increased methane $\left(\mathrm{CH}_{4}\right)$ concentrations, to air pollution levels and associated premature mortalities. We use a coupled chemistry-climate model in conjunction with global population distributions in 2000 to estimate exposure attributable to concentration changes since 1860 from each factor. Attributable mortalities are estimated using health impact functions of long-term relative risk estimates for $\mathrm{O}_{3}$ and $\mathrm{PM}_{2.5}$ from the epidemiology literature. We find global mean surface $\mathrm{PM}_{2.5}$ and health-relevant $\mathrm{O}_{3}$ (defined as the maximum 6-month mean of 1-h daily maximum $\mathrm{O}_{3}$ in a year) have increased by $8 \pm 0.16 \mu \mathrm{g} \mathrm{m}^{-3}$ and $30 \pm 0.16 \mathrm{ppbv}$ (results reported as annual average \pm standard deviation of 10 -yr model simulations), respectively, over this industrial period as a result of combined changes in emissions of air pollutants (EMIS), climate (CLIM) and $\mathrm{CH}_{4}$ concentrations (TCH4). EMIS, CLIM and $\mathrm{TCH}_{4}$ cause global population-weighted average $\mathrm{PM}_{2.5} \quad\left(\mathrm{O}_{3}\right)$ to change by $+7.5 \pm 0.19 \mu \mathrm{g} \mathrm{m}^{-3}$
\end{abstract}

( $+25 \pm 0.30 \mathrm{ppbv}),+0.4 \pm 0.17 \mu \mathrm{g} \mathrm{m}^{-3}(+0.5 \pm 0.28 \mathrm{ppbv})$, and $0.04 \pm 0.24 \mu \mathrm{g} \mathrm{m}^{-3}(+4.3 \pm 0.33 \mathrm{ppbv})$, respectively. Total global changes in $\mathrm{PM}_{2.5}$ are associated with 1.5 (95\% confidence interval, CI, 1.2-1.8) million cardiopulmonary mortalities and 95 (95\% CI, 44-144) thousand lung cancer mortalities annually and changes in $\mathrm{O}_{3}$ are associated with 375 (95\% CI, 129-592) thousand respiratory mortalities annually. Most air pollution mortality is driven by changes in emissions of short-lived air pollutants and their precursors (95\% and $85 \%$ of mortalities from $\mathrm{PM}_{2.5}$ and $\mathrm{O}_{3}$ respectively). However, changing climate and increasing $\mathrm{CH}_{4}$ concentrations also contribute to premature mortality associated with air pollution globally (by up to $5 \%$ and $15 \%$, respectively). In some regions, the contribution of climate change and increased $\mathrm{CH}_{4}$ together are responsible for more than $20 \%$ of the respiratory mortality associated with $\mathrm{O}_{3}$ exposure. We find the interaction between climate change and atmospheric chemistry has influenced atmospheric composition and human mortality associated with industrial air pollution. Our study highlights the benefits to air quality and human health of $\mathrm{CH}_{4}$ mitigation as a component of future air pollution control policy. 


\section{Introduction}

Human activities since preindustrial time have resulted in large increases in air pollution (IPCC, 2001). Measurements at various sites in the Northern Hemisphere indicate an increase from the 1860s to 2000s in surface ozone $\left(\mathrm{O}_{3}\right)$ of approximately a factor of 4 (from about 10 to $50 \mathrm{ppbv}$ ) (Gros, 2006; Marenco et al., 1994). Sulfate aerosol concentrations in Greenland ice cores suggest a factor of 3-4 increase from the mid-1860s to the present (Döscher et al., 1995; Fischer et al., 1998). Over the same period, European high-alpine glaciers indicate an increase in carbonaceous aerosols of a factor of 3 (Lavanchy et al., 1999), while Greenland icecores show little change (Lamarque et al., 2010). Sulfate and carbonaceous aerosols are key components of fine particulate matter $\left(\leq 2.5 \mu \mathrm{m}\right.$ aerodynamic diameter, $\left.\mathrm{PM}_{2.5}\right)$, which, along with $\mathrm{O}_{3}$, are pollutants that adversely impact human health (Bell et al., 2004; Jerrett et al., 2009; Krewski et al., 2009; Levy et al., 2005; Pope et al., 2002; Pope and Dockery, 2006). Here, we apply simulations of a global atmospheric chemistry-climate coupled model to investigate changes in $\mathrm{O}_{3}$ and $\mathrm{PM}_{2.5}$ from the preindustrial era to the present and their associated effects on premature mortality.

$\mathrm{O}_{3}$ is a secondary air pollutant that is formed in the troposphere by catalytic photochemical reactions of nitrogen oxides $\left(\mathrm{NO}_{\mathrm{x}}=\mathrm{NO}+\mathrm{NO}_{2}\right)$ with carbon monoxide (CO), methane $\left(\mathrm{CH}_{4}\right)$ and other volatile organic compounds (VOCs). $\mathrm{PM}_{2.5}$, including sulfate, nitrate, organic carbon (OC), black carbon (BC), secondary organic aerosol (SOA), fine dust and sea salt, is either directly emitted from various sources or produced via chemical reactions between directlyemitted gas-phase precursors (including $\mathrm{SO}_{2}, \mathrm{NO}_{\mathrm{x}}, \mathrm{NH}_{3}$, biogenic VOCs etc.) and atmospheric oxidants (i.e., $\mathrm{OH}$, $\mathrm{H}_{2} \mathrm{O}_{2}, \mathrm{O}_{3}$ ). Changes in $\mathrm{O}_{3}$ and $\mathrm{PM}_{2.5}$ concentrations from the preindustrial period to the present (1860-2000) are difficult to quantify because of sparse and uncertain preindustrial measurements, spatial heterogeneity of these species, uncertainties in estimating preindustrial emissions, and the nonlinear dependence of $\mathrm{O}_{3}$ and $\mathrm{PM}_{2.5}$ on their precursor emissions (Horowitz, 2006).

Changes in surface $\mathrm{O}_{3}$ and $\mathrm{PM}_{2.5}$ concentrations are largely controlled by changes in emissions of their precursors. Consequently, many recent studies have applied chemical transport models (CTMs) to estimate changes in tropospheric $\mathrm{O}_{3}$ and aerosol concentrations from the preindustrial era to the present (Grenfell et al., 2001; Horowitz, 2006; Lamarque et al., 2005; Mickley et al., 2001; Tsigaridis et al., 2006; Wang and Jacob, 1998). Anenberg et al. (2010) used preindustrial and present simulations from one of these CTM modeling studies (Horowitz, 2006) to estimate the effect of anthropogenic $\mathrm{O}_{3}$ and $\mathrm{PM}_{2.5}$ on present premature human mortality. However, these studies, which usually apply different emissions of short-lived species but use the same meteorological driver for preindustrial and present day simulations, do not take into account the interaction between climate and air pollution (Jacob and Winner, 2009; Isaksen et al., 2009; Fiore et al., 2012). Some short-lived species are radiatively active; therefore, they perturb climate and meteorology from regional to global scales (Naik et al., 2013; Levy et al., 2008; Shindell et al., 2008). As a result, quantifying the impact of their emission changes on air quality using CTM simulations driven by the same meteorology neglects the feedbacks between short-lived species and climate. Conversely, studies have shown that climate change can affect surface $\mathrm{O}_{3}$ and $\mathrm{PM}_{2.5}$ concentrations and thus indirectly affect human mortality (Bell et al., 2007; Fang et al., 2013; Tagaris et al., 2009). Additionally, $\mathrm{CH}_{4}$ concentration changes (from $800 \mathrm{ppbv}$ in 1860 to $1750 \mathrm{ppbv}$ in 2000) not only give a direct radiative forcing of $+0.42 \mathrm{~W} \mathrm{~m}^{-2}$ (calculated as in Ramaswamy et al., 2001), but also contribute to increasing $\mathrm{O}_{3}$ concentrations which indirectly changes climate (Shindell et al., 2009). To understand changes in surface $\mathrm{O}_{3}$ and $\mathrm{PM}_{2.5}$ over the industrial period (defined here as 1860-2000), we need to consider the effects of changing emissions of shortlived species, climate and $\mathrm{CH}_{4}$ concentrations on surface air quality and allow feedbacks between chemistry and climate to take place.

In this paper, we utilize the Geophysical Fluid Dynamics Laboratory (GFDL) Atmospheric Model, version 3 (AM3), a newly developed global 3-D model that fully couples atmospheric chemistry and climate. Our goal is to understand changes in $\mathrm{O}_{3}$ and $\mathrm{PM}_{2.5}$ from the preindustrial era to the present ("industrial" or "historic" period) and their associated effects on premature mortality. We further attribute the changing $\mathrm{PM}_{2.5}$ and $\mathrm{O}_{3}$ concentrations over this period to three factors: (1) changes in direct emissions of their constituents and precursors; (2) climate change induced changes in surface concentrations, and (3) the influence of increasing $\mathrm{CH}_{4}$ concentrations on tropospheric chemistry. For each factor, we estimate the associated impact on human health. The GFDL AM3 model and our simulations are described in Sect. 2. We evaluate simulated surface $\mathrm{O}_{3}$ and $\mathrm{PM}_{2.5}$ concentrations in Sect. 3. Changes in surface air quality are attributed to specific factors in Sect. 4. In Sect. 5, we calculate the changes in premature mortality associated with the simulated changes in air quality. Findings and conclusions are presented in Sect. 6.

\section{Methods}

\subsection{Model description}

The AM3 model (Donner et al., 2011) is the atmospheric component of the GFDL atmosphere-ocean coupled climate model CM3. AM3 is designed to address key emerging issues in climate science, including aerosol-cloud interactions and chemistry-climate feedbacks. It is GFDL's first global atmospheric model to include the indirect effects of cloudaerosol interactions (with 16 interactive aerosol species) and 
Table 1. Model simulation configurations. All simulations are run for $11 \mathrm{yr}$ with the first year used for spin-up (SST: sea surface temperature; SIC: sea ice; WMGG: well-mixed greenhouse gases; ODS: ozone-depleting substances).

\begin{tabular}{|c|c|c|c|c|c|c|}
\hline \multicolumn{2}{|c|}{ Simulations } & \multirow{2}{*}{$\begin{array}{r}\text { SST } \\
\text { and } \\
\text { SIC } \\
2000\end{array}$} & \multirow{2}{*}{$\begin{array}{c}\text { WMGG } \\
2000\end{array}$} & \multirow{2}{*}{$\frac{\text { ODS }^{\mathrm{a}}}{2000}$} & \multirow{2}{*}{$\begin{array}{c}\mathrm{CH}_{4} \\
\begin{array}{c}\text { (tropospheric } \\
\text { chemistry) }\end{array} \\
2000\end{array}$} & \multirow{2}{*}{$\begin{array}{c}\begin{array}{c}\text { Anthropogenic } \\
\text { and biomass } \\
\text { burning emissions }\end{array} \\
2000\end{array}$} \\
\hline 1 & $2000^{\mathrm{b}}$ & & & & & \\
\hline 2 & $1860^{\mathrm{b}}$ & 1860 & 1860 & 1860 & 1860 & 1860 \\
\hline 3 & 2000CL1860EM & 2000 & 2000 & 2000 & 2000 & 1860 \\
\hline 4 & 1860CL2000EM ${ }^{\mathrm{b}}$ & 1860 & 1860 & 1860 & 2000 & 2000 \\
\hline 5 & 1860ALL2000EM & 1860 & 1860 & 1860 & 1860 & 2000 \\
\hline
\end{tabular}

a The concentrations of ODS in the 1860 simulation are set to pre-1950 levels.

${ }^{\mathrm{b}}$ Simulations run for the Atmospheric Chemistry and Climate Model Intercomparison Project (ACCMIP).

of tropospheric and stratospheric chemistry (with 81 gas species) coupled with climate. Detailed chemistry, emissions, and deposition processes in AM3 are described in Naik et al. (2013) with additional details described below, and transport (advection, vertical diffusion and convection) along with physics are described in Donner et al. (2011). The model uses a finite-volume dynamical core with a $6 \times 48 \times 48$ cubedsphere horizontal grid with the grid size varying from $163 \mathrm{~km}$ (at the corners of each face) to $231 \mathrm{~km}$ (near the center of each face). Vertically, the model extends from the surface up to $0.01 \mathrm{hPa}(86 \mathrm{~km})$ with 48 vertical hybrid sigma pressure levels.

\subsection{Simulations}

To investigate the change in concentrations of $\mathrm{O}_{3}$ and $\mathrm{PM}_{2.5}$ (including simulated sulfate, nitrate, small dust, small sea salt, OC, BC, SOA) during the industrial period, we use AM3 time-slice simulations for " 1860 " and "2000". Results from these simulations were contributed to the Atmospheric Chemistry and Climate Model Intercomparison Project (ACCMIP) (Lamarque et al., 2012). We also analyze three additional sensitivity simulations. The five simulations used are summarized in Table 1 and described briefly below.

We use the "1860" and "2000" simulations to quantify the change in air quality during the industrial period. These simulations use prescribed mean climatological sea surface temperature (SST) and sea ice cover (SIC) for the decade 1860-1869 and 1995-2004, respectively, taken from one member of the 5-member ensemble historical simulation of the GFDL CM3 model conducted in support of the Intergovernmental Panel on Climate ChangeFifth Assessment Report (IPCC-AR5). Well-mixed greenhouse gases (WMGG), including $\mathrm{CO}_{2}, \mathrm{~N}_{2} \mathrm{O}, \mathrm{CH}_{4}$ and CFCs, are specified for the years 1860 and 2000 according to the database (http://www.iiasa.ac.at/webapps/tnt/RcpDb/ dsd?Actionhtmlpage $\backslash$ \&page=welcome) developed in support of the IPCC-AR5 (Meinshausen et al., 2011). Global mean $\mathrm{CH}_{4}$ concentration is specified at the surface at 1860 and 2000 levels, respectively, as lower boundary condi- tions for tropospheric chemistry calculations. Anthropogenic emissions (including from energy production, industry, land transport, maritime transport, aviation, residential and commercial sectors, solvents, agriculture, agriculture waste burning on fields, and waste) and biomass burning emissions (including from open vegetation fires in forests, savanna and grasslands) of short-lived air pollutants (i.e., $\mathrm{NO}_{\mathrm{x}}, \mathrm{CO}, \mathrm{SO}_{2}$, NMVOCs, BC and OC, etc.) for 1860 and 2000 are from the emission inventory of Lamarque et al. (2010). Anthropogenic emissions for 2000 were constructed by aggregating existing regional and global emission inventories for 40 world regions and 10 sectors. Anthropogenic emissions for 1860 were generated based on extrapolation of the historical EDGAR-HYDE emission inventory from 1890 backwards to 1850 using global fossil fuel consumption estimates from Andres et al. (1999) and regional scale data for population from the HYDE dataset (Goldewijk, 2005). Biomass burning emissions in 2000 are from the GFED2 emission inventory (van der Werf et al., 2006); the 1900-2000 biomass burning emission trend is taken from RETRO (1960-2000, Schultz et al., 2008) and GICC (1900-1950, Mieville et al., 2010) inventories; no trend is assumed between 1850 and 1900 as suggested by ice-core and charcoal records (Marlon et al., 2008; McConnell et al., 2007). The 1860 and 2000 anthropogenic and biomass burning emissions used are summarized in Table S1 of the Supplement. As described by Naik et al. (2013), all natural emissions except those that depend on the simulated meteorology (lightning $\mathrm{NO}_{\mathrm{x}}$, dimethyl sulfide (DMS), sea salt and dust emissions), are the same for both simulations. Ozone-depleting substances (ODS) are set to pre-1950 levels in the 1860 simulation and to 2000 levels in the 2000 simulation. All simulations were run for $11 \mathrm{yr}$ with the first year used as spin-up.

We define the difference in $\mathrm{PM}_{2.5}$ and $\mathrm{O}_{3}$ concentrations between the AM3 2000 and 1860 simulations as "industrial" air pollution, which reflects the total changes in air pollution levels between the start of the industrial period and 2000. Our definition of "industrial" pollution includes not only the effect of changes in short-lived air pollutant emissions, but also the effect of changes in climate, $\mathrm{CH}_{4}$ and ODS 
concentrations. It differs from the "anthropogenic" pollution defined in Anenberg et al. (2010), which was estimated as the difference between two CTM simulations with different emissions and, therefore, solely reflected the impact of emission changes on air pollution in a system that did not allow feedbacks between chemistry and climate.

To isolate the individual impacts of changes in emissions, climate, and $\mathrm{CH}_{4}$ concentrations on surface concentrations of $\mathrm{O}_{3}$ and $\mathrm{PM}_{2.5}$, we analyze three additional AM3 simulations (simulations 3, 4 and 5 in Table 1). Briefly, simulation 2000CL1860EM is the same as the 2000 simulation except it uses 1860 emissions of short-lived species; simulation 1860CL2000EM is also the same as the 2000 simulation but its SST, SIC, WMGG and ODS concentrations (applied in stratospheric chemistry and radiative forcing calculations) are set to 1860 levels; simulation 1860ALL2000EM is the same as 1860CL2000EM, but its global mean $\mathrm{CH}_{4}$ concentration is specified at 1860 levels for tropospheric chemistry calculations. Impacts of (1) changing emissions of short-lived species, (2) changing climate and (3) changing $\mathrm{CH}_{4}$ concentrations on air quality are estimated in our study as 2000-2000CL1860EM, 2000-1860CL2000EM, and 1860CL2000EM-1860ALL2000EM, respectively. In order to distinguish signals, driven by changing emissions, $\mathrm{CH}_{4}$ and climate, from internal model variability, we use annually-invariant SST, SIC and air pollutant emissions to drive 11-yr model simulations and analyze averages of the last $10 \mathrm{yr}$ of each simulation. To indicate the significance of a result, relative to the inter-annual variability due to internal model variability, we report a mean (average of all $10 \mathrm{yr}$ ) along with the standard deviation (root mean square of variance over the $10 \mathrm{yr}$ ) in the following sections (as mean $\pm \mathrm{std}$ ).

\subsection{Adverse health impacts}

We analyze the effect of changes in air pollution concentrations during the industrial period $(\sim 1860$ to $\sim 2000)$ on premature mortality using health impact functions that relate changes in air pollutant concentrations to changes in mortality. We further evaluate the relative importance of changes in emissions of air pollutants, climate change and increased $\mathrm{CH}_{4}$ concentrations on air pollution concentrations and the associated incidence of premature mortalities.

To obtain estimates of the excess mortalities ( $\Delta$ Mort) attributable to air pollution changes during the industrial period, we use health impact functions for $\mathrm{O}_{3}$ and $\mathrm{PM}_{2.5}$. These functions are based on log-linear relationships between relative risk and concentration derived from the American Cancer Society (ACS) cohort studies for adults aged 30 and older (Jerrett et al., 2009; Krewski et al., 2009; Pope et al., 2002). We apply

$\Delta$ Mort $=$ POP $\times$ Frac $\times$ Mort $_{\text {base }} \times\left(1-e^{-\beta \Delta \mathrm{C}}\right)$

in each of the AM3 surface grid cells and separately calculate changes in mortality associated with changes in $\mathrm{PM}_{2.5}$ and $\mathrm{O}_{3}$. We use the population (POP), baseline mortality (Mort ${ }_{\text {base }}$ ), and, consistent with the ACS study, the fraction of the population (Frac) $\geq 30 \mathrm{yr}$ of age in each grid cell. Changes in $\mathrm{O}_{3}$ and $\mathrm{PM}_{2.5}$ concentrations $(\Delta \mathrm{C})$ from specific factors (changes in short-lived emissions, climate, and $\mathrm{CH}_{4}$ ) from preindustrial to present day are obtained as the exposure indicators from the difference between two simulations as described in Sect. 2.2. The appropriate concentrationmortality response factor $(\beta)$ is used for each pollutant. For $\mathrm{PM}_{2.5}, \beta$ is obtained from Krewski et al. (2009), which provides the latest reanalysis of the ACS study (Pope et al., 2002). They found a $10 \mu \mathrm{g} \mathrm{m}^{-3}$ increase in $\mathrm{PM}_{2.5}$ concentrations was associated with $6 \%(95 \%$ confidence interval, CI, $4-8 \%), 13 \%(95 \% \mathrm{CI}, 10-16 \%)$ and $14 \%(95 \% \mathrm{CI}$, 6-23\%) increase in all-cause, cardiopulmonary, and lung cancer mortality, respectively. For $\mathrm{O}_{3}$, we use $(\beta)$ from Jerret et al. (2009), for which, a $10 \mathrm{ppb}$ increase in $\mathrm{O}_{3}$ is associated with a $4 \%(95 \%$ CI, $1.3-6.7 \%)$ increase in respiratory disease mortality. We use population distribution (CIESIN, 2005), fraction of adults aged 30 and older (WHO, 2003), baseline mortality for the year 2000 for lung cancer, cardiopulmonary disease, and respiratory disease mortality (WHO, 2003), as summarized in Table 2. We assume the ACS cohort studies conducted in the United States are valid globally, as relative risks characterized in US based time series studies are similar to those found in various time-series studies in Europe (Levy et al., 2005) and Asia (HEI, 2010) and no cohort studies have yet been conducted in developing countries. However, we recognize that differences exist in $\mathrm{PM}_{2.5}$ composition, health status, lifestyle, age structure, and medical attention available around the world, which could substantially affect our results.

\section{Model evaluation}

Various simulated physical and chemical parameters in AM3 have been evaluated by Donner et al. (2011) and Naik et al. (2013). Here we evaluate the ability of our 2000 AM3 simulation to reproduce observed surface $\mathrm{O}_{3}$ and $\mathrm{PM}_{2.5}$ concentrations around the world in order to increase confidence in our estimates of the excess mortalities attributable to air pollution.

We evaluate surface $\mathrm{O}_{3}$ in our 2000 simulation against surface $\mathrm{O}_{3}$ data from observational networks in the United States (Clean Air Status and Trends Network-CASTNet) and in Europe (European Monitoring and Evaluation Programme-EMEP). Sites in these two networks are well suited for evaluating global models as they represent regional $\mathrm{O}_{3}$ concentrations rather than urban plumes. A comparison between the simulated and observed seasonal cycle of $\mathrm{O}_{3}$ over twelve regions spanning the US and Europe is shown in Fig. 1. In general, like in Naik et al. (2013), the AM3 2000 simulation reproduces the observed seasonal cycle of surface $\mathrm{O}_{3}$ concentrations over most regions $(r>0.7$ and 
Table 2. Regional statistics for population and mortality rates. Population aged 30 and older (unit: million), cardiopulmonary, lung cancer and respiratory mortality rates (unit: \% per year) for regions used in this study.

\begin{tabular}{llccc}
\hline Regions & $\begin{array}{l}\text { POP } \\
(\geq 30)^{\mathrm{a}}\end{array}$ & $\begin{array}{c}\text { Cardiopulmonary } \\
\text { mortality rate }^{\mathrm{b}}\end{array}$ & $\begin{array}{c}\text { Lung cancer } \\
\text { mortality rate }^{\mathrm{b}}\end{array}$ & $\begin{array}{c}\text { Respiratory } \\
\text { mortality rate }^{\mathrm{b}}\end{array}$ \\
\hline North America & 218 & 0.609 & 0.079 & 0.092 \\
South America & 135 & 0.496 & 0.025 & 0.083 \\
Europe & 359 & 0.997 & 0.073 & 0.080 \\
Africa & 238 & 0.667 & 0.017 & 0.122 \\
South Asia & 469 & 0.744 & 0.025 & 0.132 \\
Southeast Asia & 163 & 0.588 & 0.035 & 0.139 \\
East Asia & 711 & 0.612 & 0.047 & 0.179 \\
Middle East & 97 & 0.868 & 0.039 & 0.071 \\
Rest of Asia & 65 & 1.364 & 0.064 & 0.093 \\
Australia & 11 & 0.440 & 0.065 & 0.058 \\
\hline
\end{tabular}

${ }^{\text {a }}$ CIESIN, 2005; ${ }^{\text {b }}$ WHO, 2003.
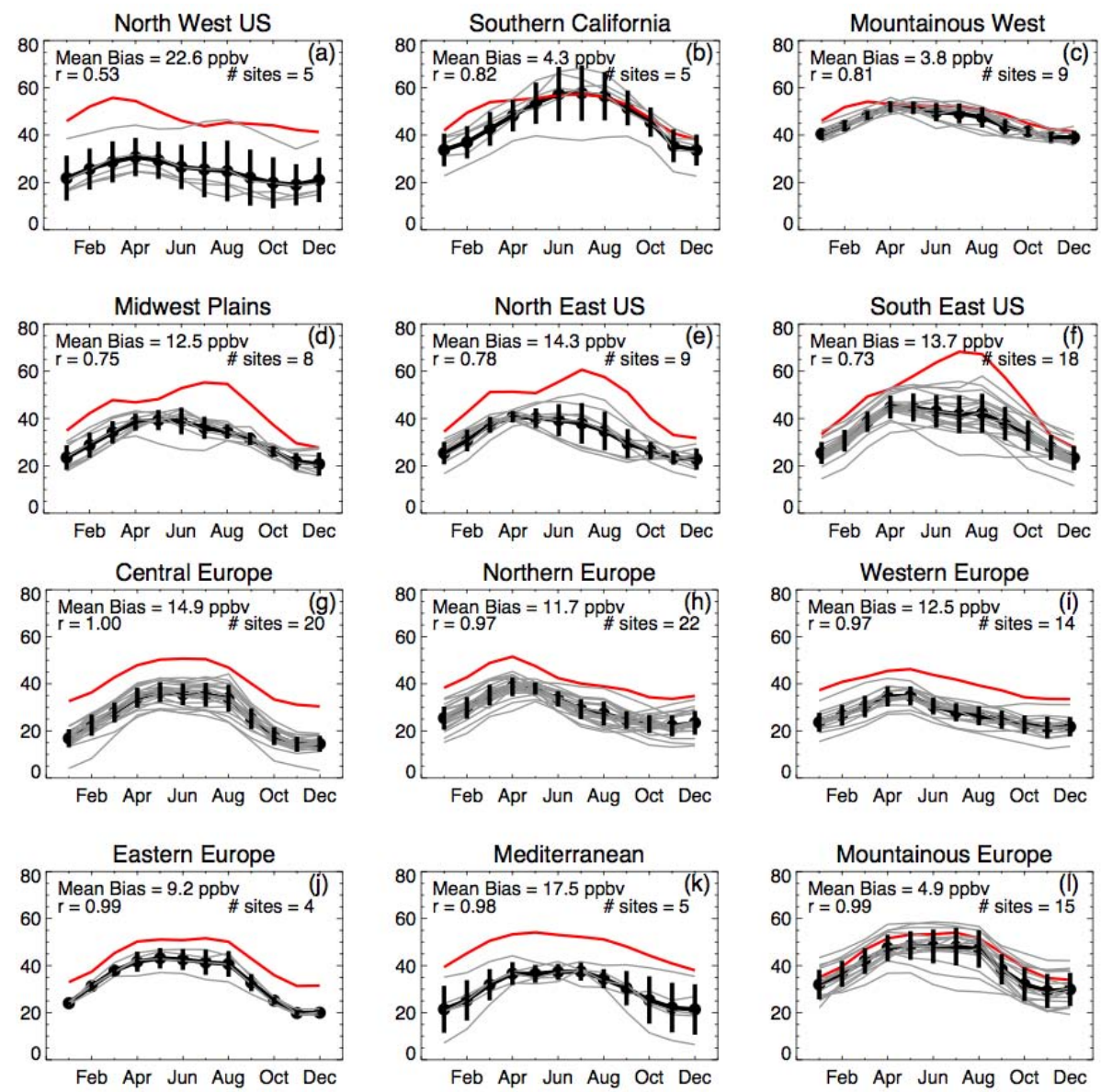

Fig. 1. Comparison of simulated monthly mean surface $\mathrm{O}_{3}$ in GFDL AM3 "2000" simulation (red line) with measurements from various regions in the United States (a-f, results from CASTNet, http://www.epa.gov/castnet/) and Europe (g-l, results from EMEP, http: //www.nilu.no/projects/ccc/emepdata.html). Observed values (black dots) represent the average of climatological monthly mean surface $\mathrm{O}_{3}$ concentrations for each site (grey lines) within each region (Table S1 in Naik et al., 2013). Vertical black lines denote standard deviation across the sites. 
bias $<20 \mathrm{ppbv}$, except in the Northwest United States). Naik et al. (2013) attribute the strong positive bias of $\mathrm{O}_{3}$ in the Northwest US to the model failure to capture the influence of maritime air masses on sites close to the ocean. Over populated areas, such as the Eastern United States, South California and Europe, surface $\mathrm{O}_{3}$ bias range from 4 ppbv to about 15 ppbv. Despite this positive bias, simulated $\mathrm{O}_{3}$ seasonal cycles follow observed cycles with correlation coefficients greater than 0.95 over all 6 European regions and greater than 0.7 elsewhere, indicating that the model is generally capturing the seasonal cycle of $\mathrm{O}_{3}$.

The optical characteristics of aerosols simulated in AM3 were evaluated in Donner et al. (2011). They found that simulated AOD was within a factor of 2 of AERONET observations. However, annual mean surface $\mathrm{PM}_{2.5}$ mass concentration simulated by AM3, which is directly associated with human mortality responses, has not yet been evaluated. Here, we evaluate annual mean $\mathrm{PM}_{2.5}$ concentrations (or its major component, sulfate, where long-term $\mathrm{PM}_{2.5}$ observations are not available) for the 2000 simulation with observations over the United States (the US Air Quality System, USAQS), Europe (EMEP) and East Asia (Acid Deposition Monitoring Network in East Asia, EANET). Measured concentrations are averaged over corresponding model grids for 19972003 and 1995-2004 for the USAQS ( $\left.\mathrm{PM}_{2.5}\right)$ and EMEP (sulfate) datasets, respectively. Asian sulfate observations are collected from Liu et al. (2009a) and Zhang et al. (2011). Figure 2 shows a consistent underestimate of total $\mathrm{PM}_{2.5}$ over the United States. However, the bias for dust (Donner et al., 2011) and sulfate over Europe and East Asia is much smaller (Fig. 2a). The greater underestimate of total $\mathrm{PM}_{2.5}$ than dust or sulfate in the AM3 2000 simulation is likely related to the simulation of SOA. AM3 SOA production is scaled directly from terpene emissions and butane oxidation (Donner et al., 2011); therefore, it may underestimate SOA away from terpene and butane sources. Additionally, AM3 does not consider SOA produced by oxidation of isoprene and does not include in-cloud mechanisms for SOA production and thus likely underestimates total SOA production. Despite the systematic $\mathrm{PM}_{2.5}$ underestimate of more than $20 \%$, AM3 captures the global spatial distribution of $\mathrm{PM}_{2.5}$ well, with a correlation coefficient above 0.9 .

\section{Surface $\mathrm{PM}_{2.5}$ and $\mathrm{O}_{3}$ concentration changes}

We first quantify the increase in surface concentrations of $\mathrm{PM}_{2.5}$ and $\mathrm{O}_{3}$ due to "industrial pollution" from preindustrial time (year 1860) to the present (year 2000) (denoted as TOTAL, Sect. 4.1). In the following subsections, we analyze the causes of these changes and attribute them to three factors: changes in emissions of air pollutants (denoted as EMIS, Sect. 4.2), climate (denoted as CLIM, Sect. 4.3) and $\mathrm{CH}_{4}$ concentrations (denoted as TCH4, Sect. 4.4).
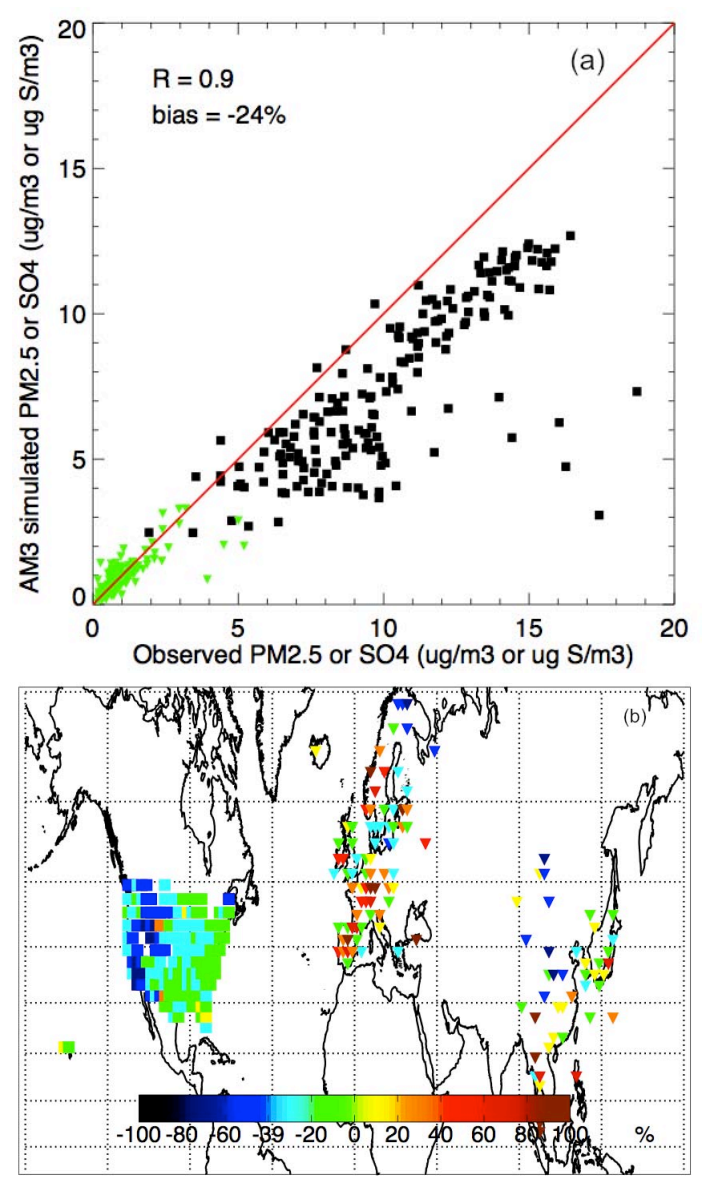

Fig. 2. (a) Scatter plot of AM3 "2000" simulated and observed annual mean concentrations of $\mathrm{PM}_{2.5}$ (black squares, corresponding to the US observations) and sulfate (green triangles, corresponding to Asian and European observations). 1:1 line is shown in red. (b) Map of the relative difference (i.e., (model-obs)/obs) in $\mathrm{PM}_{2.5}$ (squares) or sulfate (triangles). $\mathrm{PM}_{2.5}$ observations over the United States are from the US Air Quality System (AQS) Database (1997-2003 average, http://www.epa.gov/ttn/airs/airsaqs/); sulfate observations over Europe are from the European Monitoring and Evaluation Programme (EMEP, 1995-2004, http://www.emep.int/). Sulfate observations over East Asia are from the Acid Deposition Monitoring Network in East Asia (EANET, http://www.eanet.cc/ product/index.html), collected from Liu et al. (2009a) and Zhang et al. (2011).

\subsection{Total changes from 1860 to 2000}

Distributions of annual mean surface $\mathrm{PM}_{2.5}$ and healthrelevant $\mathrm{O}_{3}$ (defined as the maximum 6-month mean of 1$\mathrm{h}$ daily maximum $\mathrm{O}_{3}$ in a year, denoted as $\mathrm{H}-\mathrm{O}_{3}$ ) in year 2000 are shown in Fig. 3a and b. Global population-weighted concentrations of $\mathrm{PM}_{2.5}$ and $\mathrm{H}-\mathrm{O}_{3}$ are $13 \pm 0.15 \mu \mathrm{g} \mathrm{m}^{-3}$ and $61 \pm 0.20 \mathrm{ppbv}$ (Table 3). Both $\mathrm{PM}_{2.5}$ and $\mathrm{H}-\mathrm{O}_{3}$ show maximum concentrations near source regions in East Asia, eastern United States, India and central Africa. High concentrations of $\mathrm{PM}_{2.5}$ (ranging from 20 to $40 \mu \mathrm{g} \mathrm{m}^{-3}$ ) over 
Table 3. Year 2000 global population-weighted annual mean surface $\mathrm{PM}_{2.5}$ and $\mathrm{H}-\mathrm{O}_{3}$ (health-relevant $\mathrm{O}_{3}$, defined in Sect. 2), tropospheric mean mass-weighted $\mathrm{OH}$ and $\mathrm{H}_{2} \mathrm{O}_{2}$ concentrations, and their changes from 1860 to 2000 driven by all changes (TOTAL), changes in emissions of short-lived reactive pollutants (EMIS), changes in climate (CLIM), and changes in tropospheric $\mathrm{CH}_{4} \mathrm{Concentration}(\mathrm{TCH} 4)$. Results are reported for 10-yr model simulations as annual average \pm standard deviation.

\begin{tabular}{lrrrrr}
\hline Atmospheric species & 2000 & TOTAL & EMIS & CLIM & TCH $_{4}$ \\
\hline $\mathrm{PM}_{2.5}\left(\mu \mathrm{g} \mathrm{m}^{-3}\right)$ & $13 \pm 0.15$ & $8 \pm 0.16$ & $7.5 \pm 0.19$ & $0.4 \pm 0.17$ & $0.04 \pm 0.24$ \\
$\mathrm{H}_{3} \mathrm{O}_{3}(\mathrm{pbvv})$ & $61 \pm 0.20$ & $30 \pm 0.16$ & $25 \pm 0.30$ & $0.5 \pm 0.28$ & $4.3 \pm 0.33$ \\
$\mathrm{OH}\left(10^{6}\right.$ molecules cm & -3 \\
$\mathrm{H}_{2} \mathrm{O}_{2}\left(10^{10}\right.$ molecules cm $\left.^{-3}\right)$ & $1.19 \pm 0.01$ & $-0.11 \pm 0.01$ & $0.13 \pm 0.01$ & $-0.02 \pm 0.01$ & $-0.24 \pm 0.01$ \\
\hline
\end{tabular}

northern Africa and the Middle East are associated with strong dust emissions. Present-day tropospheric air massweighted $\mathrm{OH}$ and $\mathrm{H}_{2} \mathrm{O}_{2}$ concentrations are $1.19 \pm 0.01 \times 10^{6}$ and $1.95 \pm 0.01 \times 10^{10}$ molec $\mathrm{cm}^{-3}$ (Table 3). The global mean $\mathrm{OH}$ concentration in the 2000 simulation is consistent with the climatological mean of Spivakovsky et al. (2000). It results in a $\mathrm{CH}_{4}$ lifetime in the 2000 simulation of about $9 \mathrm{yr}$, consistent with the estimate in Prather et al. (2012).

Total changes in $\mathrm{PM}_{2.5}$ and $\mathrm{H}-\mathrm{O}_{3}$ from preindustrial to present (2000-1860), shown in Fig. 3c and d, reflect changes in pollutant concentrations resulting from changes in all factors between 1860 and 2000 (TOTAL). During industrialization, concentrations of air pollution increased over most regions, particularly over populated areas in the Northern Hemisphere. Global population-weighted annual mean $\mathrm{PM}_{2.5}$ and $\mathrm{H}-\mathrm{O}_{3}$ increased from 1860 to 2000 by $8 \pm 0.16 \mu \mathrm{g} \mathrm{m}^{-3}$ and $30 \pm 0.16 \mathrm{ppbv}$, respectively (Table 3 ). Because of the coincidence of large concentration increases and densely populated areas, population-weighted global mean concentration changes for $\mathrm{PM}_{2.5}$ and $\mathrm{O}_{3}$ are substantially higher than their land-only area-weighted mean values $\left(3 \pm 0.10 \mu \mathrm{g} \mathrm{m}^{-3}\right.$ and $\left.20 \pm 0.12 \mathrm{ppbv}\right)$. Increases in $\mathrm{PM}_{2.5}$ and $\mathrm{O}_{3}$ during the industrial period account for $61 \%$ and $49 \%$, respectively, of their year 2000 concentrations.

Our simulated population-weighted changes in $\mathrm{PM}_{2.5}$ and $\mathrm{O}_{3}$ from 1860 to 2000 are smaller than those reported in Anenberg et al. (2010) $\left(15.0 \mu \mathrm{g} \mathrm{m}^{-3}\right.$ and $\left.37.1 \mathrm{ppbv}\right)$, in large part due to the use of different present and preindustrial emissions in the two studies. We use emission inventories specific for years 1860 and 2000 from Lamarque et al. (2010) that are described in Sect. 2.2. This preindustrial inventory reflects the best current understanding that preindustrial anthropogenic emissions were significant while preindustrial biomass burning emissions could be higher than they were in 2000 in some regions (Lamarque et al., 2010; Mieville et al., 2010). The emission inventory we chose is widely used in various climate (and chemistry-climate) models in support of the IPCC AR5 report and the ACCMIP Project (Lamarque et al., 2010, 2012).

In contrast, the 2000 emissions of Anenberg et al. (2010) were obtained by scaling their standard 1990 emissions (taken from EDGAR v2.0) by the 2000 to 1990 ratio of SRES emissions (Nakicenovic et al., 2000) in four geopolitical regions (Horowitz, 2006). Their preindustrial fossil fuel emissions are assumed to be zero, while their preindustrial emissions from burning of biofuels, savannah, tropical forest and agricultural waste are assumed to be $10 \%$ of their standard 1990 emissions. Preindustrial emissions of $\mathrm{NO}_{\mathrm{x}}, \mathrm{CO}, \mathrm{BC}$ and OC in Anenberg et al. (2010) are all lower than in this study (see Supplement, Table S2).

The resulting differences in preindustrial and present emissions between the two studies are large. For example, the historical increase in $\mathrm{SO}_{2}$ emissions in this study and in Anenberg et al. (2010) is 100 and $150 \mathrm{Tg}$ per year, respectively; $\mathrm{BC}$ emission changes differ by even more, 4.4 vs. $10 \mathrm{Tg} \mathrm{C}$ per year, respectively; differences in $\mathrm{NO}_{\mathrm{x}}$ emission changes are 31.7 vs. $35.0 \mathrm{Tg} \mathrm{N}$ per year. The greater emission changes from 1860 to 2000 in Anenberg et al. (2010) than in our study drive their higher estimate of changes in surface $\mathrm{PM}_{2.5}$ and $\mathrm{O}_{3}$. Finally, in addition to differences in emission inventories, our study intrinsically differs from Anenberg et al. (2010) as changes in $\mathrm{PM}_{2.5}$ and $\mathrm{O}_{3}$ from 1860-2000 here result from changes in climate, ODS and $\mathrm{CH}_{4}$ as well as from emission changes.

In the following subsections, we separately explore the role of historical changes in emissions of short-lived species, climate and $\mathrm{CH}_{4}$ on surface $\mathrm{PM}_{2.5}$ and $\mathrm{O}_{3}$, using sensitivity simulations introduced in Sect. 2.2.

\subsection{Impact of changes in emissions of short-lived species}

Here we quantify how historical changes in short-lived species emissions affect surface air quality by comparing the 2000 simulation with a simulation with 2000 climate (SST, SIC and WMGG) but 1860 emissions of short-lived species (2000CL1860EM). Global $\mathrm{CH}_{4}$ concentrations applied as the lower boundary condition for tropospheric chemistry calculations are specified at 2000 levels in both simulations.

Distributions of surface $\mathrm{PM}_{2.5}$ and $\mathrm{H}-\mathrm{O}_{3}$ changes resulting from changes in short-lived air pollutant emissions are shown in Fig. 3e and $f(2000-2000$ CL1860EM). Changing emissions raises the global annual mean populationweighted concentration of $\mathrm{PM}_{2.5}$ by $7.5 \pm 0.19 \mu \mathrm{g} \mathrm{m}^{-3}$ (Table 3), accounting for $94 \%$ of the total change in $\mathrm{PM}_{2.5}$ from 1860 to 2000. The $\mathrm{PM}_{2.5}$ pattern resulting from changes in 


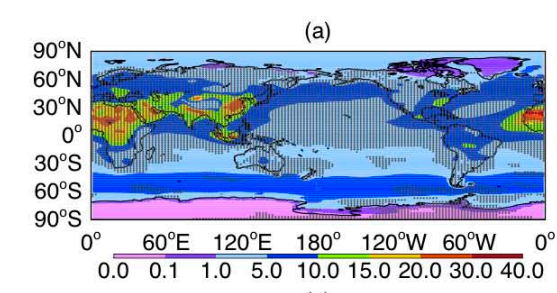

(c)

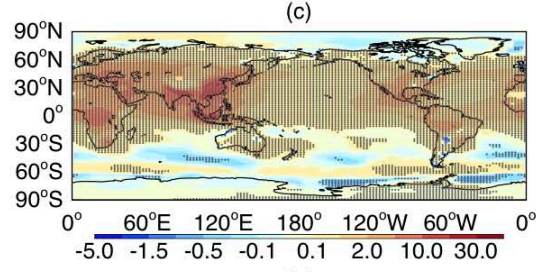

(e)

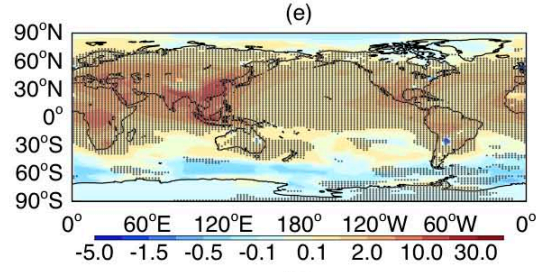

(g)

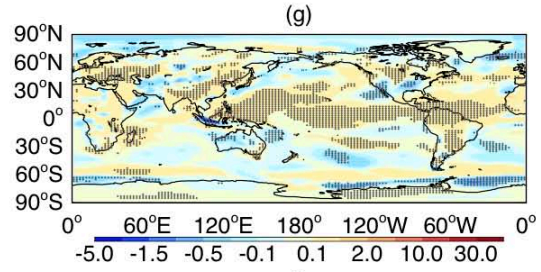

(i)

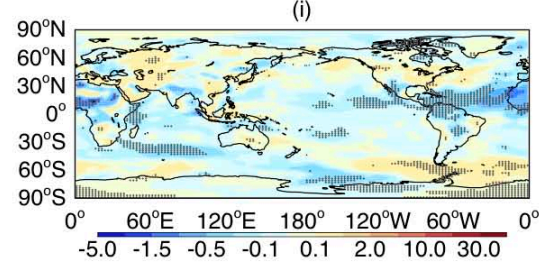

(b)

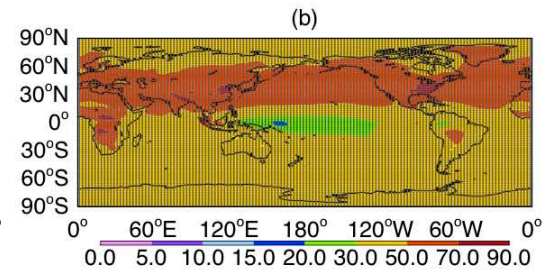

(d)

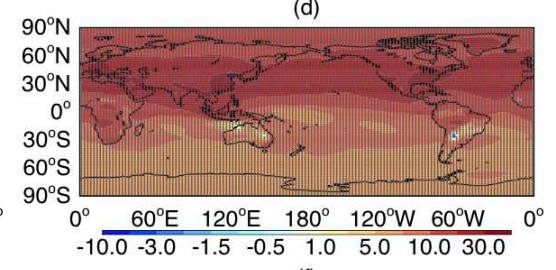

(f)

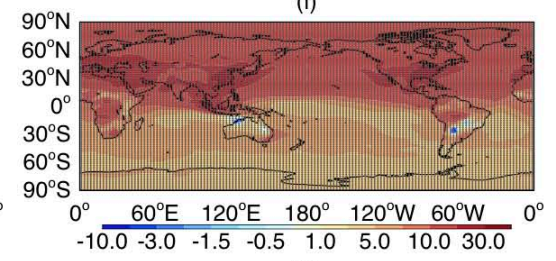

(h)

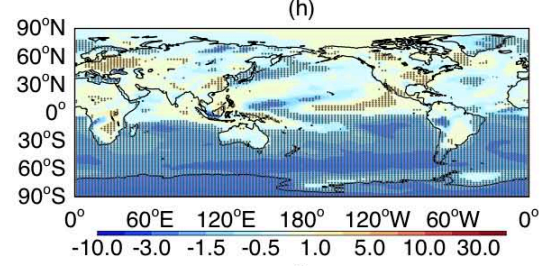

(j)

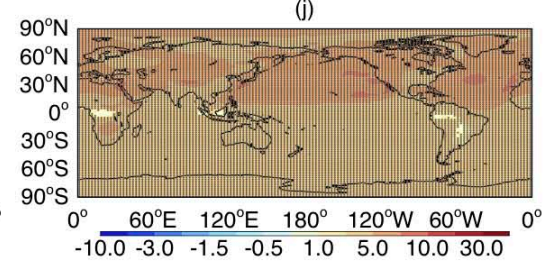

Fig. 3. Annual $\mathrm{PM}_{2.5}$ (left, unit: $\mu \mathrm{g} \mathrm{m}^{-3}$ ) and $\mathrm{H}-\mathrm{O}_{3}$ (right, unit: ppbv) surface concentration in 2000 (row 1 , a and $\mathbf{b}$ ), their total changes from preindustrial to present day ("2000" minus "1860" simulations) (row 2, c and d), and changes over that time interval due to anthropogenic air pollutant emissions only ("2000" minus "2000CL1860EM" simulations) (row 3, e and f), due to climate change only ("2000" minus "1860CL2000EM" simulations) (row 4, $\mathbf{g}$ and $\mathbf{h}$ ), and due to the impact of $\mathrm{CH}_{4}$ increases on tropospheric chemistry only ("1860CL2000EM" minus "1860ALL2000EM" simulations) (row 5, i and $\mathbf{j}$ ). Dotted areas indicate changes significant at the $95 \%$ confidence level as assessed by student t-test.

short-lived pollutant emissions (Fig. 3e) is strongly correlated ( $R=0.99)$ with the pattern of the total changes resulting from all three factors between 1860 and 2000 (Fig. 3c).

Emission changes applied in this study include both anthropogenic and biomass burning emissions, both of which were influenced by human activity during the industrial period. Anthropogenic emissions increase during the industrial period almost everywhere while changes in biomass burning emissions driven by human activities vary in sign depending on location. For example, from 1860 to 2000, sulfate concentrations increase everywhere, especially in the Northern Hemisphere mid-latitudes, driven by enhanced emissions of anthropogenic precursors (e.g. a factor of 18 increase in sul- fur dioxide emissions, Table 2 in Naik et al., 2013). However, $\mathrm{BC}$ and OC decrease over the US while increasing over central Africa and tropical South America. This is driven by a decrease in biomass burning in the United States and an increase in the tropics between 1860 and 2000 (Fig. 8 in Naik et al., 2013). According to Mieville et al. (2010), in boreal regions, burnt surface area and biomass burning emissions have decreased over the past one to two centuries as a result of human-induced land-use change and fire suppression policy. In contrast, over central Africa, central South America and Indonesia, biomass burning emissions have increased over the past few decades due to human pressure and the 
use of fire for deforestation as part of agriculture expansion (Mieville et al., 2010).

We found that increases in $\mathrm{O}_{3}$ precursor emissions from preindustrial time to the present lead to $45 \%$ and $40 \%$ increases in the photochemical production and loss of $\mathrm{O}_{3}$, respectively, leading to a $21 \%$ increase in the tropospheric $\mathrm{O}_{3}$ burden. As a result, the global mean population-weighted $\mathrm{H}-\mathrm{O}_{3}$ increases by $25 \pm 0.30 \mathrm{pbbv}$ (Table 3 ). Although the distribution of emission-driven changes in $\mathrm{H}^{-\mathrm{O}_{3}}$ (Fig. 3f) correlates well with that of the total change in $\mathrm{H}-\mathrm{O}_{3}$ from 1860 to 2000 (Fig. 3d, $R=0.99$ ), the emission-driven increase of $\mathrm{H}-\mathrm{O}_{3}$ accounts for only $83 \%$ of the total increase $(30 \pm 0.16 \mathrm{ppbv})$, indicating that other factors also influence changes in $\mathrm{H}-\mathrm{O}_{3}$ concentrations. We show in Sects. 4.3 and 4.4 that changing climate and increased $\mathrm{CH}_{4}$ concentrations drive the rest of the $\mathrm{H}-\mathrm{O}_{3}$ increase.

Due to increases in emissions of short-lived species, aerosols become more abundant in the atmosphere and are associated with decreased precipitation in the AM3 model (Donner et al., 2011). In our study, feedbacks from increased concentrations of short-lived species lead to global precipitation decreases of $0.03 \mathrm{~mm} \mathrm{day}^{-1}$ with large decreases (about $1 \mathrm{~mm} \mathrm{day}^{-1}$ ) over source regions such as East Asia. As a result, sulfate lifetime to wet deposition increases from 6.4 days in 1860 to 6.9 days in 2000. Increases in emissions of short-lived species also cause a net negative all-sky radiative forcing $\left(-1.43 \mathrm{~W} \mathrm{~m}^{-2}\right.$, including both direct and indirect radiation), cooling the atmosphere and reducing chemical reaction rates (although this effect varies locally depending on the location and type of aerosols).

\subsection{Impact of historical climate change}

Historical climate change indirectly affects surface $\mathrm{PM}_{2.5}$ and $\mathrm{O}_{3}$ by modifying transport patterns, precipitation, water vapor, and temperature-dependent reaction rates. Here we estimate the effect of historical climate change on surface $\mathrm{PM}_{2.5}$ and $\mathrm{O}_{3}$ by comparing the 2000 simulation with a simulation with emissions of short-lived species set at 2000 levels but with year 1860 SST, SIC and WMGG (1860CL2000EM). The global average $\mathrm{CH}_{4}$ concentration in 2000 is applied as the lower boundary condition for tropospheric chemistry calculations in both simulations. This allows us to isolate the role of climate change on air quality from the impact of $\mathrm{CH}_{4}$ on tropospheric chemistry. The two simulations analyzed here have different ODS concentrations (Table 1), therefore, the impact of historical climate change also includes the effects of stratospheric $\mathrm{O}_{3}$ depletion caused by anthropogenic ODS emissions over the period. Our historical climate change does not include the climate change induced effect on emissions of biogenic hydrocarbons, such as isoprene and terpenes that are air pollutant precursors. If a biogenic air pollutant precursor emission response to the changing climate were included, it would likely increase our estimate of the changes in $\mathrm{PM}_{2.5}$ and $\mathrm{O}_{3}$ concentrations described below.

\subsection{1 $\quad \mathrm{PM}_{2.5}$}

From 1860 to 2000, our simulation indicates that climate change caused global population-weighted $\mathrm{PM}_{2.5}$ concentrations to increase by $0.4 \pm 0.17 \mu \mathrm{g} \mathrm{m}^{-3}$ (Table 3), accounting for $5 \%$ of the total increase over this period. The spatial distribution of $\mathrm{PM}_{2.5}$ change driven by climate change and that driven by all factors together are loosely correlated $(R=0.3)$. Changes in $\mathrm{PM}_{2.5}$ driven by climate change show a complicated pattern (Fig. 3g): modest increases (up to $2 \mu \mathrm{g} \mathrm{m}^{-3}$ ) occur over East Asia, South and South-east Asia, west Africa and Central Europe; significant decreases (up to $1.5 \mu \mathrm{g} \mathrm{m}^{-3}$ ) occur over the United States, central Asia, and central and western Australia. Significant decreases over central and western Australia are driven by lower concentrations of sea salt and dust (not shown), two $\mathrm{PM}_{2.5}$ components with emissions dependent on meteorology. Increases that are statistically significant over Asia, India and central Europe are driven by increases in $\mathrm{BC}$, sulfate and $\mathrm{OC}$, with $\mathrm{OC}$ accounting for a majority of the enhanced $\mathrm{PM}_{2.5}$. Increases in the concentration of these species is driven by reductions in large-scale precipitation, the major driver of wet deposition (Fig. 4, Fang et al., 2011). Increases also result from higher $\mathrm{H}_{2} \mathrm{O}_{2}$ concentrations $\left(+0.15 \pm 0.03 \times 10^{10}\right.$ molec cm $^{-3}$, Table 3) that increase the aqueous phase production of sulfate. Decreases in $\mathrm{PM}_{2.5}$ over the United States and central Asia are driven by stronger large-scale precipitation/wet deposition close to their $\mathrm{PM}_{2.5}$ precursor source regions (Fig. 4). While changes in $\mathrm{PM}_{2.5}$ driven by climate change are statistically significant over most continental regions, $10-\mathrm{yr}$ simulations are likely too short to generate a robust signal for precipitation distinguishable from noise on a regional scale (Naik et al., 2013). Figure 4 shows that simulated differences in large-scale precipitation is significant at the $95 \%$ confidence level over part of East Asia, north India and Central Europe and many ocean regions, but is not significant elsewhere. If we lower the confidence level to $90 \%$, regions with statistically significant differences in precipitation become larger over Asia and India (see Supplement, Fig. S1). We realize that the spatial distribution of $\mathrm{PM}_{2.5}$ responses to historical climate change can be highly variable and uncertain, because of inconsistencies associated with changes in regional precipitation, precipitation frequencies and regional ventilation, as suggested in Jacob and Winner (2009). Future studies applying similar simulations as ours from various models in the ACCMIP project will help to further evaluate the robustness of $\mathrm{PM}_{2.5}$ response to historical climate change.

\subsubsection{Ozone}

As a result of historical climate change and stratospheric $\mathrm{O}_{3}$ depletion, the global population-weighted $\mathrm{H}-\mathrm{O}_{3}$ 


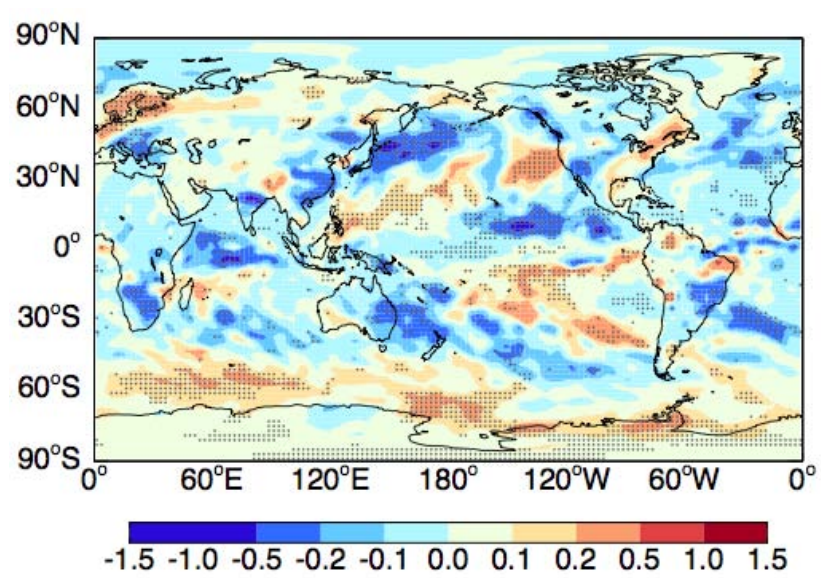

Fig. 4. Changes in annual mean stratiform (large-scale) precipitation (unit: $\mathrm{mm} \mathrm{day}^{-1}$ ) driven by climate change (derived as "2000" - "1860CL2000emis" simulations). Dotted areas indicate changes significant at the $95 \%$ confidence level as assessed by student t-test.

concentration increases by $0.5 \pm 0.28 \mathrm{ppbv}$ (Table 3 ), accounting for less than $2 \%$ of the total historical $\mathrm{H}-\mathrm{O}_{3}$ change. Despite the small contribution, the spatial distribution of $\mathrm{H}$ $\mathrm{O}_{3}$ changes driven by climate change follows that driven by all factors with a correlation coefficient of 0.71 . Historical climate change leads to increases in $\mathrm{O}_{3}$ over polluted areas and at high-latitudes in the Northern Hemisphere, while decreasing $\mathrm{O}_{3}$ over remote regions and oceans (Fig. 3h). This pattern, similar to that of surface $\mathrm{O}_{3}$ responses to a warmer future climate (Fang et al., 2013; Liao et al., 2006; Murazaki and Hess, 2006), is mainly associated with the tropospheric chemistry of $\mathrm{O}_{3}$ under a warmer and wetter atmosphere. $\mathrm{O}_{3}$ decreases over remote oceanic regions is largely driven by an increase in water vapor (total column water vapor increases by $3 \%$ from preindustrial times), which leads to increases in $\mathrm{HO}_{\mathrm{x}}\left(\mathrm{HO}_{\mathrm{x}}=\mathrm{OH}+\mathrm{HO}_{2}\right)$ concentrations $\left(+3.6 \pm 0.1 \times 10^{6}\right.$ molec $\left.\mathrm{cm}^{-3}\right)$. Reaction with $\mathrm{HO}_{\mathrm{x}}$ is the primary sink of $\mathrm{O}_{3}$ at low $\mathrm{NO}_{\mathrm{x}}$ concentrations. However, surface $\mathrm{O}_{3}$ increases by up to 3 ppbv over regions with large $\mathrm{NO}_{\mathrm{x}}$ emissions such as south China, north India, northeast United States, central Europe and central Africa. Factors contributing to $\mathrm{O}_{3}$ increases over these regions include: (1) increased $\mathrm{O}_{3}$ production due to higher water vapor leading to more abundant $\mathrm{HO}_{\mathrm{x}}$ which leads to increased $\mathrm{O}_{3}$ production at high $\mathrm{NO}_{\mathrm{x}}$ concentrations; (2) increased global average temperature $\left(+0.5^{\circ} \mathrm{C}\right)$ from 1860 to 2000 , increases photochemistry rates and decreases net formation of peroxyacetyl nitrate $\left(\mathrm{PAN}, \mathrm{CH}_{3} \mathrm{C}(\mathrm{O}) \mathrm{OONO}_{2}\right)$, a reservoir species for $\mathrm{NO}_{\mathrm{x}}$, leaving more $\mathrm{NO}_{\mathrm{x}}$ available over source regions which promotes local $\mathrm{O}_{3}$ production; and (3) increased lightning that increases production of lightning $\mathrm{NO}_{\mathrm{x}}(+3 \%)$. While lightning $\mathrm{NO}_{\mathrm{x}}$ is mostly formed in the upper free troposphere and contributes to stronger tropospheric $\mathrm{O}_{3}$ production, its contribution to surface $\mathrm{O}_{3}$ is small, most likely over regions where subsidence brings lightning-affected air masses to the surface, such as the southwestern United States (Fang et al., 2010).

Since 1950, anthropogenic emissions of ODS have caused stratospheric $\mathrm{O}_{3}$ depletion. Stratospheric $\mathrm{O}_{3}$ depletion and the associated changes in photochemical reaction rates in the troposphere, combined with changes in transport between the stratosphere and troposphere, also affects tropospheric $\mathrm{O}_{3}$. To estimate this effect on surface $\mathrm{O}_{3}$, we first evaluate changes in the cross-tropopause $\mathrm{O}_{3}$ fluxes, and find the net flux decreases by almost $15 \%$ relative to its level in the 1860 simulation. To estimate the stratospheric $\mathrm{O}_{3}$ contribution to surface $\mathrm{O}_{3}$, we analyze a tracer of stratospheric $\mathrm{O}_{3}$ implemented in these simulations $\left(\mathrm{O}_{3 \mathrm{~S}}\right)$. This tracer, as described in Lin et al. (2012), is defined as $\mathrm{O}_{3}$ above the World Meteorological Organization (WMO) thermal tropopause at each model time step. Once mixed into tropospheric air, $\mathrm{O}_{3 \mathrm{~S}}$ is subject to the same transport and loss as tropospheric $\mathrm{O}_{3}$. Surface $\mathrm{O}_{3 \mathrm{~S}}$ shows an annual global mean reduction of $0.7 \mathrm{ppbv}$, resulting from both stratospheric $\mathrm{O}_{3}$ depletion leading to less $\mathrm{O}_{3}$ transport from the stratosphere to troposphere, and stronger $\mathrm{O}_{3}$ destruction in the troposphere. Surface $\mathrm{O}_{3 \mathrm{~S}}$ change has distinctive seasonal variations, with smaller decreases $(-0.2 \mathrm{ppbv})$ in winter than in summer $(-1.3 \mathrm{ppbv})$, consistent with projections that stratospheric-tropospheric exchange of $\mathrm{O}_{3}$ increases in winter months in a warming climate (Collins et al., 2003; Liao et al., 2006; Zeng and Pyle, 2003). The decrease in $\mathrm{O}_{3}$ s concentration at the surface suggests that historical changes in stratospheric $\mathrm{O}_{3}$ tend to decrease surface $\mathrm{O}_{3}$ concentrations. However, this surface $\mathrm{O}_{3 \mathrm{~S}}$ change likely overestimates changes in the stratospheric contribution to surface $\mathrm{O}_{3}$ since any $\mathrm{O}_{3}$ above the thermal tropopause is instantly labeled as "stratospheric" regardless of its actual origin (Lin et al., 2012).

\subsection{Impact of increased $\mathrm{CH}_{4}$ concentration}

The simulated change in $\mathrm{H}-\mathrm{O}_{3}$ and $\mathrm{PM}_{2.5}$ due to climate change explored in Sect. 4.3 does not allow changes in $\mathrm{CH}_{4}$ concentration to affect tropospheric chemistry (Table 1). Although this configuration intentionally isolates the role of climate change, increases in $\mathrm{CH}_{4}$ concentrations from 1860 to 2000 also affect tropospheric chemistry and hence surface $\mathrm{O}_{3}$ and $\mathrm{PM}_{2.5}$ concentrations. We estimate the effect of increased $\mathrm{CH}_{4}$ concentrations on $\mathrm{O}_{3}$ and $\mathrm{PM}_{2.5}$ concentrations by taking the difference between the 1860CL2000EM and 1860ALL2000EM simulations (Fig. 3i and j). Both simulations are identical except that the global mean $\mathrm{CH}_{4}$ concentrations applied in the tropospheric chemistry calculations are set to year 2000 (1750 ppbv) and 1860 (800 ppbv) levels, respectively.

Tropospheric $\mathrm{CH}_{4}$ perturbs the concentrations of oxidizing agents in the atmosphere, which in turn affect $\mathrm{PM}_{2.5}$ and $\mathrm{O}_{3}$ concentrations. In addition, $\mathrm{CH}_{4}$ is a precursor of tropospheric ozone. Reaction with $\mathrm{CH}_{4}$ is 
a primary sink of atmospheric $\mathrm{OH}$. Higher $\mathrm{CH}_{4}$ concentrations in 2000 than 1860 result in an $\mathrm{OH}$ decrease of $0.24 \pm 0.01 \times 10^{6}$ molec $\mathrm{cm}^{-3}$ and an increase of $0.35 \pm 0.03 \times 10^{10}$ molec cm $\mathrm{cm}^{-3}$ in $\mathrm{H}_{2} \mathrm{O}_{2}$ (Table 3). As $\mathrm{OH}$ and $\mathrm{H}_{2} \mathrm{O}_{2}$ are associated with the gas-phase and in-cloud production of sulfate, changing $\mathrm{CH}_{4}$ thus indirectly influences $\mathrm{PM}_{2.5}$. Compensating changes in $\mathrm{OH}$ and $\mathrm{H}_{2} \mathrm{O}_{2}$ lead to a small and insignificant global change in $\mathrm{PM}_{2.5}$ (global population-weighted $\mathrm{PM}_{2.5}$ decreases by $0.04 \pm 0.24 \mu \mathrm{g} \mathrm{m}^{-3}$, Table 3). The spatial pattern of $\mathrm{PM}_{2.5}$ changes driven by the impact of increased $\mathrm{CH}_{4}$ concentration is also not correlated with its total change during the industrial period.

$\mathrm{CH}_{4}$ increases (from $800 \mathrm{ppbv}$ in 1860 to $1750 \mathrm{ppbv}$ in 2000) result in an increase in the global population-weighted $\mathrm{H}-\mathrm{O}_{3}$ concentration of $4.3 \pm 0.33$ ppbv (Table 3 , TCH4), accounting for almost $15 \%$ of the total $\mathrm{H}-\mathrm{O}_{3}$ produced during the industrial period. The fraction that $\mathrm{CH}_{4}$ contributes to total $\mathrm{H}-\mathrm{O}_{3}$ produced during the industrial period is much higher ( $22 \%$ over land) if it is weighted by area. The distribution of surface $\mathrm{O}_{3}$ enhancement driven by increased $\mathrm{CH}_{4}$ is significant everywhere in the world and is approximately $5-10 \mathrm{ppbv}$ in the Northern Hemisphere and $2-5 \mathrm{ppbv}$ in the Southern Hemisphere (Fig. 3j). A spatial correlation of 0.7 between changes in surface $\mathrm{H}-\mathrm{O}_{3}$ driven by increased $\mathrm{CH}_{4}$ and that driven by all factors supports total $\mathrm{O}_{3}$ changes being partly driven by $\mathrm{CH}_{4}$. Although the impact of $\mathrm{CH}_{4}$ on $\mathrm{O}_{3}$ has been discussed in previous literature (Dentener et al., 2005; Fiore et al., 2002, 2008; West et al., 2006), most of these studies focus on the potential benefit of future $\mathrm{CH}_{4}$ mitigation while our study examines the total change in $\mathrm{O}_{3}$ resulting from historic increases in $\mathrm{CH}_{4}$. However, the magnitude of $\mathrm{CH}_{4}$ impact on $\mathrm{O}_{3}$ in those studies is consistent with ours: for example, Fiore et al. (2008) estimate that anthropogenic $\mathrm{CH}_{4}$ emissions contribute 5 ppbv to global mean surface $\mathrm{O}_{3}$; West et al. (2006) and Anenberg et al. (2009) find that a $20 \%$ reduction in anthropogenic $\mathrm{CH}_{4}$ and a $20 \%$ reduction in global $\mathrm{CH}_{4}$ mixing ratio lead to approximately a 1 ppbv decrease in global mean surface $\mathrm{O}_{3}$.

\section{Premature mortalities associated with industrial air pollution}

\subsection{Estimate of premature mortalities associated with changes in $\mathrm{PM}_{2.5}$ and $\mathrm{O}_{3}$ concentrations during the industrial period}

We estimate excess mortalities attributable to industrial air pollution separately for $\mathrm{O}_{3}$ and $\mathrm{PM}_{2.5}$, using population and baseline mortality rates at present (2000) along with concentration changes in $\mathrm{O}_{3}$ and $\mathrm{PM}_{2.5}$ from 1860 to 2000. Globally, in 2000, industrial $\mathrm{PM}_{2.5}$ is associated with 1.53 (95\% CI, of 1.03-1.98) million cardiopulmonary mortalities and 95 (95\% CI, 44-144) thousand lung cancer mortalities per year (Table 4); while industrial $\mathrm{O}_{3}$ is associated with 0.37 (95\% CI, 0.13-0.59) million respiratory mortalities per year (Table 4). Our estimates suggest that about 1.5 million cardiopulmonary and 95 thousand lung cancer mortalities associated with $\mathrm{PM}_{2.5}$ exposure, and 0.37 million respiratory mortalities associated with $\mathrm{O}_{3}$ exposure would have been avoided in 2000 if surface $\mathrm{PM}_{2.5}$ and $\mathrm{O}_{3}$ had remained at 1860 levels (i.e., anthropogenic and biomass burning emissions of air pollutants, $\mathrm{CH}_{4}$ and climate had all remained the same in 2000 as they were in 1860). Our estimated mortalities associated with industrial $\mathrm{PM}_{2.5}$ and $\mathrm{O}_{3}$ are considerably lower than those in Anenberg et al. (2010), which is consistent with differences between our emission scenarios and calculated surface concentrations and theirs, as discussed in Sect. 4.1. If we apply a low concentration threshold (LCT) of $5.8 \mu \mathrm{g} \mathrm{m}^{-3} \mathrm{PM}_{2.5}$ and $33.3 \mathrm{ppbv} \mathrm{O}_{3}$ (the lowest values in the ACS studies), premature mortalities associated with industrial $\mathrm{PM}_{2.5}$ and $\mathrm{O}_{3}$ are $15 \%$ and $11 \%$ lower, respectively. These relative differences are smaller here than in Anenberg et al. (2010) (33\% and $28 \%$, respectively for mortalities associated with $\mathrm{PM}_{2.5}$ and $\mathrm{O}_{3}$ ) because our preindustrial emissions and hence simulated preindustrial $\mathrm{O}_{3}$ and $\mathrm{PM}_{2.5}$ are higher than theirs (see Sect. 4.1 and Table S1). As differences with and without use of the LCT are relatively small in our study, we hereafter only report mortalities without the LCT.

We separate the world into 10 regions as in Liu et al. (2009b) and Fang et al. (2013) to estimate the regional mortalities associated with industrial air pollution. The regional distribution of premature mortality associated with industrial $\mathrm{PM}_{2.5}$ and $\mathrm{O}_{3}$ is shown in Fig. 5. Eastern China and northern India are hotspots for air pollution mortalities, driven by their large increases in surface $\mathrm{PM}_{2.5}$ and $\mathrm{O}_{3}$ concentrations and their large populations. East Asia accounts for $43 \%(56 \%)$ of the global cardiopulmonary (lung cancer) mortalities associated with industrial $\mathrm{PM}_{2.5}$ and $50 \%$ of the global respiratory mortalities associated with industrial $\mathrm{O}_{3}$. South Asia is second, accounting for $27 \%(16 \%)$ of the global cardiopulmonary (lung cancer) mortalities associated with industrial $\mathrm{PM}_{2.5}$ and $19 \%$ of the global respiratory mortalities associated with industrial $\mathrm{O}_{3}$. None of the other regions contribute over $15 \%$ to the global mortalities associated with industrial air pollution.

\subsection{Attribution of premature mortalities associated with industrial air pollution to changing emissions of short-lived pollutants, climate and methane concentrations}

In Sect. 4, changes in surface $\mathrm{O}_{3}$ and $\mathrm{PM}_{2.5}$ from 1860 to 2000 are attributed to changes in air pollutant emissions, climate and $\mathrm{CH}_{4}$ concentrations. Here, we estimate the mortality responses using Eq. (1) with concentration changes driven by each factor separately. We further evaluate the relative importance of each factor to total air pollution mortalities in 2000 by comparing the mortality response associated with 
Table 4. Premature mortalities in 2000 associated with industrial air pollution. Values are calculated as in Eq. (1), using ACS health impact functions, concentration difference in annual $\mathrm{PM}_{2.5}$ and $\mathrm{H}-\mathrm{O}_{3}$ between " 1860 " and "2000" simulations, WHO baseline mortality rate and population in the year 2000. The $95 \%$ confidence intervals are shown in brackets.

\begin{tabular}{lrrr}
\hline \multirow{2}{*}{ Regions } & \multicolumn{2}{c}{ Change in Premature mortalities $(1000$ s deaths $)$} \\
\cline { 2 - 4 } & $\begin{array}{r}\mathrm{PM}_{2.5} \text { mortality } \\
\text { (Chronic, cardiopulmonary) }\end{array}$ & $\begin{array}{r}\mathrm{PM}_{2.5} \text { mortality } \\
\text { (Chronic, lung cancer) }\end{array}$ & $\begin{array}{r}\mathrm{O}_{3} \text { mortality } \\
\text { (Chronic, respiratory) }\end{array}$ \\
\cline { 2 - 4 } World & $1532(1214,1832)$ & $95(44,144)$ & $375(129,592)$ \\
North America & $38(30,46)$ & $4.4(2.0,6.9)$ & $26(9,41)$ \\
South America & $15(12,18)$ & $0.8(0.4,1.3)$ & $5(2,8)$ \\
Europe & $125(99,152)$ & $8.2(3.7,12.7)$ & $31(11,49)$ \\
Africa & $77(61,93)$ & $2.1(0.9,3.2)$ & $19(6,30)$ \\
South Asia & $417(331,499)$ & $15(7,23)$ & $70(24,111)$ \\
Southeast Asia & $108(86,130)$ & $6.9(3.2,10.5)$ & $27(9,43)$ \\
East Asia & $661(527,788)$ & $53(25,79)$ & $183(64,287)$ \\
Middle East & $52(41,63)$ & $2.6(1.2,4.0)$ & $7.5(2.6,12.0)$ \\
Rest of Asia & $29(23,35)$ & $1.4(0.6,2.3)$ & $5.5(2.6,8.8)$ \\
Australia & $0.7(0.5,0.8)$ & $0.1(0.05,0.2)$ & $0.3(0.1,0.4)$ \\
\hline
\end{tabular}

each factor with that associated with the three factors together for each region and globally (the number of mortalities in each region associated with each factor is summarized in Table S3 of the Supplement). To provide a quantitative assessment of their relative importance, for each region $(i)$, a normalized mortality contribution (NMC) is defined in the following way:

$\mathrm{NMC}_{i}=\frac{\text { Mortality response driven by one factor }}{\text { Mortality response driven by all factors }}$

and analyzed for each factor in the following discussion.

We first estimate the global mortality response associated with industrial $\mathrm{PM}_{2.5}$ and $\mathrm{O}_{3}$ pollution resulting from changes in air pollutant emissions only (2000 2000CL1860EM, EMIS). We find that if air pollutant emissions in year 2000 had remained at 1860 levels, 1.49 (95\% CI, 1.18-1.79) million cardiopulmonary mortalities, 92 (95\% CI, 43-140) thousand lung cancer mortalities associated with $\mathrm{PM}_{2.5}$ exposure and 0.33 (95\% CI, 0.11-0.52) million respiratory mortalities associated with $\mathrm{O}_{3}$ exposure could have been avoided.

We next estimate the global mortality response associated with industrial $\mathrm{PM}_{2.5}$ and $\mathrm{O}_{3}$ pollution resulting from climate change (and stratospheric $\mathrm{O}_{3}$ depletion) (2000 1860CL2000EM). We find that if climate and stratospheric $\mathrm{O}_{3}$ in 2000 were the same as in 1860 , about $91(95 \% \mathrm{CI}$, 71-110) thousand cardiopulmonary mortalities, 5 (95\% CI, 2-8) thousand lung cancer mortalities associated with $\mathrm{PM}_{2.5}$ exposure and 7 (95\% CI, 2-12) thousand respiratory mortalities associated with $\mathrm{O}_{3}$ exposure could have been avoided.

Then, we evaluate the effects of $\mathrm{CH}_{4}$ concentration increases on global premature mortalities associated with air pollution. To be entirely consistent with the previous comparisons, we would compare $\mathrm{PM}_{2.5}$ and $\mathrm{O}_{3}$ in simulation 2000 with that in a simulation identical to simulation 2000 except with the lower boundary condition of global $\mathrm{CH}_{4}$ concentration specified at 1860 instead of 2000 levels in its tropospheric chemistry calculation. Unfortunately, such a simulation is not available. However, two of our available simulations (1860CL2000EM and 1860ALL2000EM), although simulating 1860 climate, differ only in their treatments of $\mathrm{CH}_{4}$ in tropospheric chemistry. This allows us to estimate the effect of increased $\mathrm{CH}_{4}$ on premature mortality due to $\mathrm{O}_{3}$ and $\mathrm{PM}_{2.5}$ exposure. We assume the bias due to the difference between 1860 and 2000 climates is small. Our results suggest that if $\mathrm{CH}_{4}$ had remained at 1860 levels (about 950 ppbv less than the year 2000 level), about 50 (95\% CI, 17-82) thousand respiratory mortalities would have been avoided due to lower $\mathrm{O}_{3}$ concentrations resulting from less $\mathrm{CH}_{4}$. Our estimated $\mathrm{O}_{3}$ mortalities associated with industrial $\mathrm{CH}_{4}$ increase is comparable with previous estimates in the literature that focused on the health benefits of $\mathrm{CH}_{4}$ mitigation. For example, both West et al. (2006) and Anenberg et al. (2009) find a $20 \%$ reduction in anthropogenic $\mathrm{CH}_{4}$ emissions or a $20 \%$ reduction in global $\mathrm{CH}_{4}$ concentrations (both equivalent to about 300 ppbv $\mathrm{CH}_{4}$ concentration reduction) would reduce cardiopulmonary mortalities by $16-17$ thousand.

We finally assess the relative importance of each factor to air pollution mortality regionally and globally. Figure 6 shows NMC for each region. Due to the non-linearity in the health impact function, chemistry, and chemistry-climate system, the value of each bar in Fig. 6 is close to, but not exactly, 1.

Global premature mortality associated with industrial $\mathrm{PM}_{2.5}$, is dominated by increased emissions of reactive air pollutants $(\sim 95 \%)$, however, climate change is influential with a global NMC of $\sim 5 \%$. Regionally, contributions of climate change to cardiopulmonary and lung cancer mortality associated with industrial $\mathrm{PM}_{2.5}$ can be as high as $14 \%$ with the highest values over Europe and Australia. The 
(a)

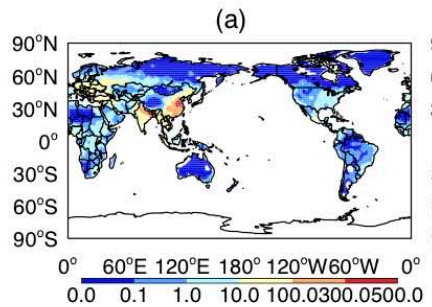

(d)

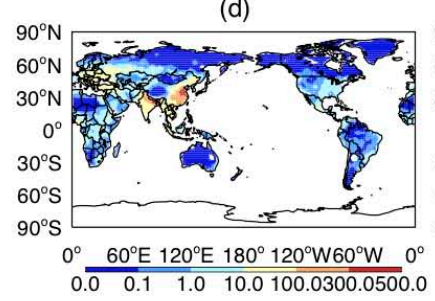

(g)

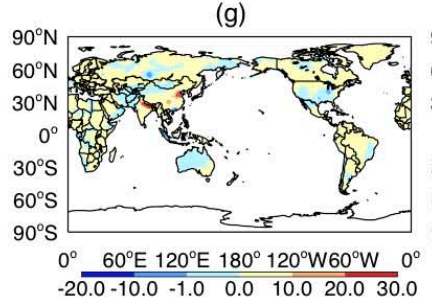

(j)

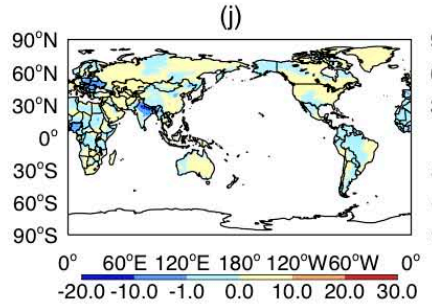

(b)

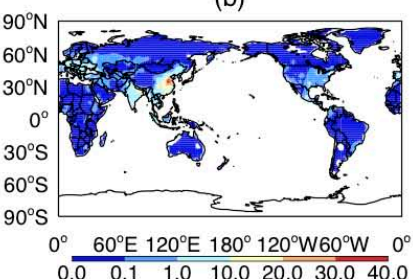

(e)

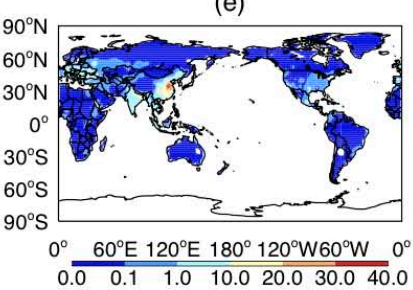

(h)

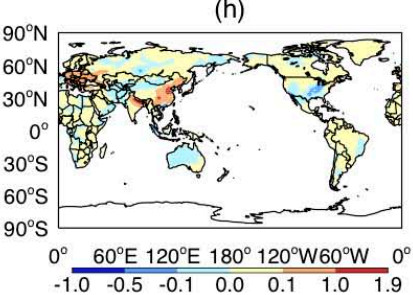

(k)

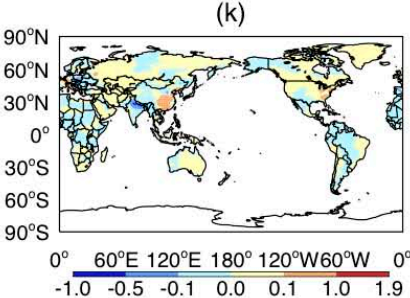

(c)

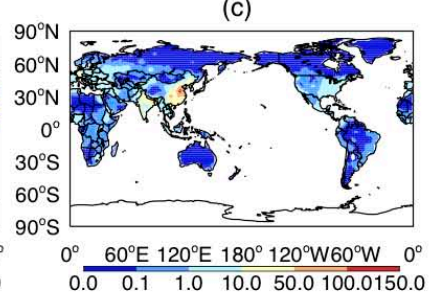

(f)

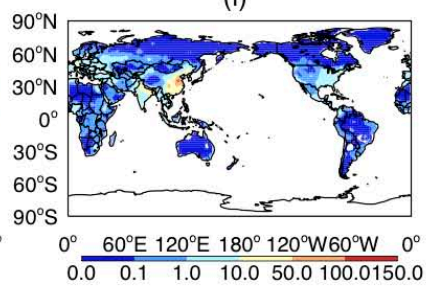

(i)

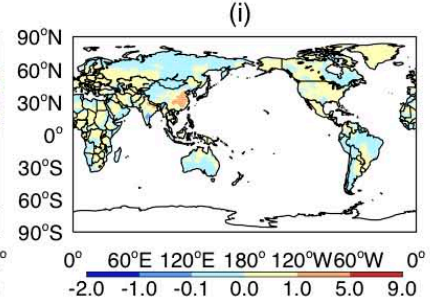

(I)

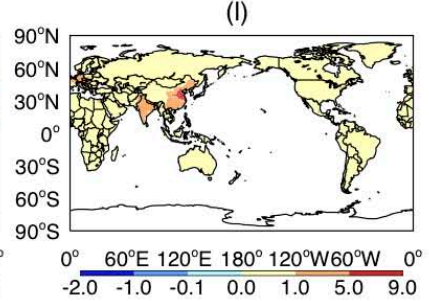

Fig. 5. Annual cardiopulmonary (a, d, g, j), lung cancer (b, e, h, k) and respiratory mortalities (c, f, i, l) (unit: deaths $\left./ 1000 \mathrm{~km}{ }^{2}\right)$ attributed to total changes in $\mathrm{PM}_{2.5}$ and $\mathrm{O}_{3}$ from preindustrial to present ("2000" minus "1860" simulations) (row 1, a, b and c); changes in $\mathrm{PM}_{2.5}$ and $\mathrm{O}_{3}$ over that time interval due to increases in short-lived anthropogenic air pollutant emissions only ("2000" minus "2000CL1860EM" simulations) (row 2, d, e and f); due to climate change only ("2000" minus "1860CL2000EM" simulations) (row 3, g, h and i); and due to the impact of $\mathrm{CH}_{4}$ increases on tropospheric chemistry only ("1860CL2000EM" minus "1860ALL2000EM" simulations) (row 4, j, $\mathbf{k}$ and $\mathbf{l}$ ).

impact of increased $\mathrm{CH}_{4}$ concentrations on $\mathrm{PM}_{2.5}$ and associated premature mortality globally is insignificant (Table 3).

The global premature respiratory mortality associated with industrial $\mathrm{O}_{3}$ is also dominated by increased emissions of short-lived air pollutants (more than $85 \%$ ). However increases in $\mathrm{CH}_{4}$ are also influential with a global NMC of $13 \%$. Regionally, NMC of increased $\mathrm{CH}_{4}$ to $\mathrm{O}_{3}$ ranges from 10 to $33 \%$ with the largest increases in excess mortalities in regions where increases in short-lived air pollutant emissions are relatively low (i.e., Australia, South America and Africa). Thus respiratory mortalities from industrial $\mathrm{O}_{3}$ over those relatively clean regions are more affected by rising global background $\mathrm{CH}_{4}$ concentrations than other regions. The contribution of climate change is small with a global NMC of about $1 \%$.

\section{Discussion and conclusions}

In this study, we apply the GFDL Atmospheric Model version 3 (AM3), a global chemistry-climate model, to examine changes in surface $\mathrm{O}_{3}$ and $\mathrm{PM}_{2.5}$ from the preindustrial period to the end of the 20th century and associated changes in premature mortality. Simulated global population-weighted $\mathrm{PM}_{2.5}$ and $\mathrm{H}-\mathrm{O}_{3}$ (health-related $\mathrm{O}_{3}$, defined as the maximum 6-month mean of 1-h daily maximum $\mathrm{O}_{3}$ in a year) concentrations increase by $8 \pm 0.16 \mu \mathrm{g} \mathrm{m}^{-3}$ and $30 \pm 0.16 \mathrm{ppbv}$, respectively, from the preindustrial period to the present (1860 to 2000). We quantify excess mortalities attributable to industrial air pollution and find that around year 2000, industrial $\mathrm{PM}_{2.5}$ is associated with 1.53 (95\% CI, 1.21-1.83) million cardiopulmonary disease and 95 (95\% CI, 44-144) thousand lung cancer; industrial $\mathrm{O}_{3}$ is associated with 0.37 (95\% CI, 0.13-0.59) million annual respiratory mortalities. 

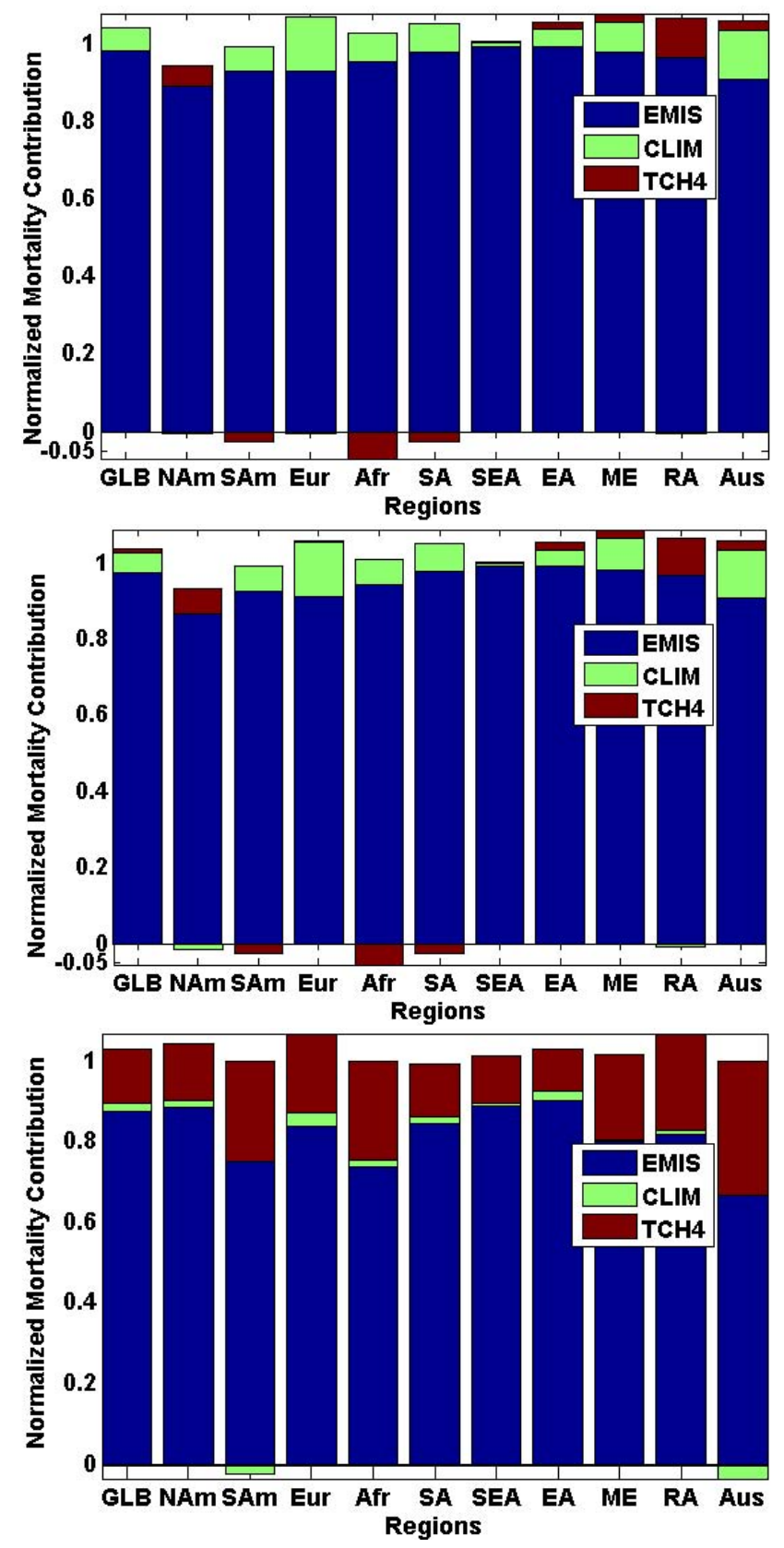

Fig. 6. Normalized Mortality Contribution of (a) cardiopulmonary and (b) lung cancer associated with surface $\mathrm{PM}_{2.5}$ and of (c) respiratory disease associated with $\mathrm{O}_{3}$ over each region. Blue, green and dark red represent the impact of changes in emissions of short-lived species, climate change and the impact of $\mathrm{CH}_{4}$ change on tropospheric chemistry, respectively. Labels on the x-axis represent the following regions: Global, North America, South America, Europe, Africa, South Asia, Southeast Asia, East Asia, Middle East, Rest of Asia, and Australia, as in Fang et al. (2013).

India and China suffer most from industrial air pollution mortality as they have experienced strong increases in air pollution levels and have large exposed populations.
We further evaluate the relative importance of changes in emissions of short-lived species, climate, and $\mathrm{CH}_{4}$ concentrations in driving changes in $\mathrm{PM}_{2.5}, \mathrm{O}_{3}$ and associated premature mortalities.

We find that increases in short-lived air pollutant emissions from 1860 to 2000 lead to $7.5 \pm 0.19 \mu \mathrm{g} \mathrm{m}^{-3}$ and $25 \pm 0.30$ ppbv increases in $\mathrm{PM}_{2.5}$ and $\mathrm{H}-\mathrm{O}_{3}$ concentrations respectively, accounting for a majority (94\% and $83 \%$ ) of total increases in these two species over this period. Changes in emissions of short-lived pollutants account for over $95 \%$ of cardiopulmonary or lung cancer mortalities associated with industrial $\mathrm{PM}_{2.5}$ and over $85 \%$ of respiratory mortalities associated with industrial $\mathrm{O}_{3}$.

$\mathrm{CH}_{4}$ concentration increase is the second most important driver of $\mathrm{H}-\mathrm{O}_{3}$ increases, causing an increase of $4.3 \pm 0.33$ ppbv and accounting for almost $15 \%$ of the total increase of $\mathrm{H}-\mathrm{O}_{3}$ from 1860 to $2000 . \mathrm{CH}_{4}$ contributes nearly $15 \%$ of the total respiratory mortalities associated with industrial $\mathrm{O}_{3} \cdot \mathrm{CH}_{4}$ has negligible effects on $\mathrm{PM}_{2.5}$ and has an insignificant effect on lung cancer or cardiopulmonary mortalities associated with $\mathrm{PM}_{2.5}$.

Changing climate has a small role in driving $\mathrm{O}_{3}$ change during the industrial period, causing an increase of $0.5 \pm 0.28 \mathrm{ppbv}$ in global $\mathrm{H}_{-} \mathrm{O}_{3}$ ( $2 \%$ of the total increase) from 1860 to 2000. Climate change is the second most important driver of changes in $\mathrm{PM}_{2.5}$ during the industrial period, causing an increase of $0.4 \pm 0.17 \mu \mathrm{g} \mathrm{m}^{-3}$ (5\% of its total increase) from 1860 to 2000 . The effect of climate change on industrial air pollution mortalities is small but non-negligible for both $\mathrm{PM}_{2.5}$ and $\mathrm{O}_{3}$, accounting for $<5 \%$ and $\sim 2 \%$ of changes in mortality associated with these species, respectively.

The contribution of climate change and $\mathrm{CH}_{4}$ concentration increases together to excess mortalities over various regions ranges from $1 \%$ to $14 \%$ for cardiopulmonary and lung cancer mortality associated with industrial $\mathrm{PM}_{2.5}$ and from $8 \%$ to $33 \%$ for respiratory mortality associated with industrial $\mathrm{O}_{3}$. Increased $\mathrm{CH}_{4}$ concentrations alone contribute more than $20 \%$ to respiratory mortalities associated with industrial $\mathrm{O}_{3}$ exposure over South America, Europe, Africa, Middle East and Rest of Asia. Recent projections indicate that over Europe and the United States local $\mathrm{O}_{3}$ precursor emissions are likely to continue to decrease after 2000 (Richter et al., 2005; van der A et al., 2008). In the meantime, $\mathrm{CH}_{4}$ is projected to increase in almost all SRES (Nakicenovic et al., 2000) and RCP (Meinshausen et al., 2011) emission scenarios (except RCP2.6 and SRES B2). As a result, the relative contribution of increased $\mathrm{CH}_{4}$ to $\mathrm{O}_{3}$ mortality will likely continue to rise, increasing the relative health benefits of $\mathrm{CH}_{4}$ mitigation.

As the benefit of $\mathrm{CH}_{4}$ reduction does not depend on its location, for cleaner regions, such as Europe, South America and Australia (where we find mortality burdens are more sensitive to $\mathrm{CH}_{4}$ concentrations than other regions), identifying low-cost $\mathrm{CH}_{4}$ mitigation options internationally may be an 
effective method of reducing local premature mortalities associated with $\mathrm{O}_{3}$ exposure. Our study highlights the benefits of controlling $\mathrm{CH}_{4}$ emissions as part of air quality policy.

Many opportunities to mitigate $\mathrm{CH}_{4}$ are available (UNEP, 2011). Anenberg et al. (2012) examined potential measures and showed that, relative to the 2030 reference scenario and population, implementing available $\mathrm{CH}_{4}$ measures would avoid around 70 thousand deaths due to respiratory disease associated with $\mathrm{O}_{3}$ exposure. We estimate industrial $\mathrm{O}_{3}$ respiratory mortalities to be approximately 375 thousand in the year 2000 (Table 3), This suggests that, with currently available $\mathrm{CH}_{4}$ mitigation measures, respiratory mortalities associated with industrial $\mathrm{O}_{3}$ pollution could be reduced by nearly $20 \%$.

Modeling estimates of industrial air pollution and associated excess mortalities strongly depend on emission changes applied during this period, as reflected by differences between this study and Anenberg et al. (2010). They also depend on simulated physical, dynamical and chemical processes in the atmosphere. To evaluate the robustness of our results, similar studies using different chemistryclimate models could be conducted. Many of the simulations applied in this study were conducted under the ACCMIP Project. Multiple modeling groups have participated in this project, all of which use the same emission inventories and run simulations for preindustrial (1860) and present (2000) (http://www.giss.nasa.gov/projects/accmip/ specifications.html). Further analysis of the ACCMIP simulations (http://www.atmos-chem-phys-discuss.net/special_ issue176.html) could reduce uncertainties in modeling estimates of industrial air pollution and associated mortalities.

\section{Supplementary material related to this article is available online at: http://www.atmos-chem-phys.net/13/ 1377/2013/acp-13-1377-2013-supplement.pdf.}

Acknowledgements. The authors would like to acknowledge the Atmospheric Chemistry and Climate Model Intercomparison Project (ACCMIP) for designing the experimental protocol, which was applied in simulations used in this study. The authors are also grateful for efforts of GFDL's Global Atmospheric Model Development Team in the development of the GFDL-AM3 and Modeling Services Group.

Edited by: C. H. Song

\section{References}

Andres, R. J., Fielding, D. J., Marland, G., Boden, T. A., Kumar, N., and Kearney, A. T.: Carbon dioxide emissions from fossilfuel use, 1751-1950, Tellus B, 51, 759-765, doi:10.1034/j.16000889.1999.t01-3-00002.x, 1999.

Anenberg, S. C., West, J. J., Fiore, A. M., Jaffe, D. A., Prather, M. J., Bergmann, D., Cuvelier, C., Dentener, F. J., Duncan, B. N., Gauss, M., Hess, P., Jonson, J. E., Lupu, A., MacKenzie, I. A., Marmer, E., Park, R. J., Sanderson, M., Schultz, M., Shindell, D. T., Szopa, S., Garcia Vivanco, M., Wild, O., and Zeng, G.: Intercontinental impacts of ozone pollution on human mortality, Environ. Sci. Technol., 43, 6482-6487, 2009.

Anenberg, S. C., Horowitz, L. W., Tong, D. Q., and West, J. J.: An Estimate of the Global Burden of Anthropogenic Ozone and Fine Particulate Matter on Premature Human Mortality Using Atmospheric Modeling, Environ. Health Perspect., 118, 1189-1195, doi:10.1289/ehp.0901220, 2010.

Anenberg, S. C., Schwartz, J., Shindell, D., Amann, M., Faluvegi, G., Klimont, Z., Maenhout, G., Pozzoli, L., van Dingenen, R., Vignati, E., Emberson, L., Muller, N. Z., West, J. J., Williams, M., Demkine, V., Hicks, W. K., Kuylenstierna, J., Raes, F., and Ramanathan, V.: Global air quality and health co-benefits of mitigating near-term climate change through methane and black carbon emission controls, Environ. Health Perspect., 120, 831-839, 2012.

Bell, M. L., McDermott, A., Zeger, S. L., Samet, J. M., and Dominici, F.: Ozone and Short-term Mortality in 95 US Urban Communities, 1987-2000, JAMA: The Journal of the American Medical Association, 292, 2372-2378, doi:10.1001/jama.292.19.2372, 2004.

Bell, M. L., Goldberg, R., Hogrefe, C., Kinney, P., Knowlton, K., Lynn, B., Rosenthal, J., Rosenzweig, C., and Patz, J.: Climate change, ambient ozone, and health in 50 US cities, Climatic Change, 82, 61-76, doi:10.1007/s10584-006-9166-7, 2007.

CIESIN, Center for International Earth Science Information Network, Columbia University; and Centro Internacional de Agricultura Tropical (CIAT), Gridded Population of the World, Version 3 (GPWv3). Palisades, NY: Socioeconomic Data and Applications Center (SEDAC), Columbia University, available at: http://sedac.ciesin.columbia.edu/gpw (last access: August 2012), 2005.

Collins, W. J., Derwent, R. G., Garnier, B., Johnson, C. E., Sanderson, M. G., and Stevenson, D. S.: Effect of stratospheretroposphere exchange on the future tropospheric ozone trend, J. Geophys. Res., 108, 8528, doi:10.1029/2002jd002617, 2003.

Dentener, F., Stevenson, D., Cofala, J., Mechler, R., Amann, M., Bergamaschi, P., Raes, F., and Derwent, R.: The impact of air pollutant and methane emission controls on tropospheric ozone and radiative forcing: CTM calculations for the period 19902030, Atmos. Chem. Phys., 5, 1731-1755, doi:10.5194/acp-51731-2005, 2005.

Donner, L. J., Wyman, B. L., Hemler, R. S., Horowitz, L. W., Ming, Y., Zhao, M., Golaz, J.-C., Ginoux, P., Lin, S.-J., Schwarzkopf, D. M., Austin, J., Alaka, G., Cooke, W. F., Delworth, T. L., Freidenreich, S. M., Gordon, C. T., Griffies, S. M., Held, I. M., Hurlin, W. J., Klein, S. A., Knutson, T. R., Langenhorst, A. R., Lee, H.-C., Lin, Y., Magi, B. I., Malyshev, S. L., Milly, P. C. D., Naik, V., Nath, M. J., Pincus, R., Ploshay, J. J., Ramaswamy, V., Seman, C. J., Shevliakova, E., Sirutis, J. J., Stern, W. F., Stouffer, 
R. J., Wilson, R. J., Winton, M., Wittenberg, A. T., and Zeng, F.: The Dynamical Core, Physical Parameterizations, and Basic Simulation Characteristics of the Atmospheric Component AM3 of the GFDL Global Coupled Model CM3, J. Climate, 34843519, doi:10.1175/2011JCLI3955.1, 2011.

Döscher, A., Gäggeler, H. W., Schotterer, U., and Schwikowski, M.: A 130 years deposition record of sulfate, nitrate and chloride from a high-alpine glacier, Water Air Soil Pollut., 85, 603-609, doi:10.1007/bf00476895, 1995.

Fang, Y., Fiore, A. M., Horowitz, L. W., Levy, H., II, Hu, Y., and Russell, A. G.: Sensitivity of the $\mathrm{NO}_{y}$ budget over the United States to anthropogenic and lightning $\mathrm{NO}_{\mathrm{x}}$ in summer, J. Geophys. Res., 115, D18312, doi:10.1029/2010jd014079, 2010.

Fang, Y., Fiore, A. M., Horowitz, L. W., Gnanadesikan, A., Held, I., Chen, G., Vecchi, G., and Levy, H.: The impacts of changing transport and precipitation on pollutant distributions in a future climate, J. Geophys. Res., 116, D18303, doi:10.1029/2011JD015642, 2011.

Fang, Y., Mauzerall, D. L., Liu, J., Fiore, A. M., and Horowitz, L. W.: Impacts of 21 st century climate change on global air pollution-related premature mortality, Climatic Change, in revision, 2013.

Fiore, A. M., Jacob, D. J., Field, B. D., Streets, D. G., Fernandes, S. D., and Jang, C.: Linking ozone pollution and climate change: The case for controlling methane, Geophys. Res. Lett., 29, 1919, doi:10.1029/2002g1015601, 2002.

Fiore, A. M., West, J. J., Horowitz, L. W., Naik, V., and Schwarzkopf, M. D.: Characterizing the tropospheric ozone response to methane emission controls and the benefits to climate and air quality, J. Geophys. Res., 113, D08307, doi:10.1029/2007jd009162, 2008.

Fiore, A. M., Naik, V., Spracklen, D. V., Steiner, A., Unger, N., Prather, M., Bergmann, D., Cameron-Smith, P. J., Cionni, I., Collins, W. J., Dalsoren, S., Eyring, V., Folberth, G. A., Ginoux, P., Horowitz, L. W., Josse, B., Lamarque, J.-F., MacKenzie, I. A., Nagashima, T., O’Connor, F. M., Righi, M., Rumbold, S. T., Shindell, D. T., Skeie, R. B., Sudo, K., Szopa, S., Takemura, T., and Zeng, G., Global air quality and climate, Chem. Soc. Rev., 41, 6663-6683, doi:10.1039/C2CS35095E, 2012.

Fischer, H., Wagenbach, D., and Kipfstuhl, J.: Sulfate and nitrate firn concentrations on the Greenland ice sheet 2. Temporal anthropogenic deposition changes, J. Geophys. Res., 103, 2193521942, doi:10.1029/98jd01886, 1998.

Goldewijk, K. K.: Three centuries of global population growth: a spatial referenced population (density) database for 1700-2000, Popul. Environ., 26, 343-367, doi:10.1007/s11111-005-3346-7, 2005.

Grenfell, J. L., Shindell, D. T., Koch, D., and Rind, D.: Chemistryclimate interactions in the Goddard Institute for Space Studies general circulation model 2. New insights into modeling the preindustrial atmosphere, J. Geophys. Res., 106, 33435-33451, doi:10.1029/2000jd000090, 2001.

Gros, V.: Background ozone and long distance transport of nitrogen oxides, global change magazine for schools, published by ACCENT, available at: http://www.atmosphere.mpg.de/enid/ Nr2JuneO5Research5og.html (last access: August 2012), 2006.

HEI: Public Health and Air Pollution in Asia (PAPA): Coordinated Studies of Short-Term Exposure to Air Pollution and Daily Mortality in Four Cities, Health Effects Institute Boston, MA, USA,
2010.

Horowitz, L. W.: Past, present, and future concentrations of tropospheric ozone and aerosols: Methodology, ozone evaluation, and sensitivity to aerosol wet removal, J. Geophys. Res., 111, D22211, doi:10.1029/2005jd006937, 2006.

Isaksen, I. S. A., Granier, C., Myhre, G., Berntsen, T. K., Dalsøren, S. B., Gauss, M., Klimont, Z., Benestad, R., Bousquet, P., Collins, W., Cox, T., Eyring, V., Fowler, D., Fuzzi, S., Jöckel, P., Laj, P., Lohmann, U., Maione, M., Monks, P., Prevot, A. S. H., Raes, F., Richter, A., Rognerud, B., Schulz, M., Shindell, D., Stevenson, D. S., Storelvmo, T., Wang, W.-C., van Weele, M., Wild, M., and Wuebbles, D.: Atmospheric composition change: Climate-chemistry interactions, Atmos. Environ., 43, 5138-5192, doi:10.1016/j.atmosenv.2009.08.003, 2009.

IPCC: Climate Change 2001: The Scientific Basis. Contribution of Working Group I to the Third Assessment Report of the Intergovernmental Panel on Climate Change, edited by: Houghton, J. T., Ding, Y., Griggs, D. J., Noguer, M., van der Linden, P. J., Dai, X., Maskell, K., and Johnson, C. A., Cambridge University Press, Cambridge, United Kingdom, 1000 pp., 2001.

Jacob, D. J. and Winner, D. A.: Effect of climate change on air quality, Atmos. Environ., 43, 51-63, doi:10.1016/j.ATMOSENV.2008.09.051, 2009.

Jerrett, M., Burnett, R. T., Pope, A. C., Ito, K., Thurston, G., Krewski, D., Shi, Y., Calle, E., and Thun, M.: Long-Term Ozone Exposure and Mortality, New England Journal of Medicine, 360, 1085-1095, doi:10.1056/NEJMoa0803894, 2009.

John, J. G., Fiore, A. M., Naik, V., Horowitz, L. W., and Dunne, J. P.: Climate versus emission drivers of methane lifetime against loss by tropospheric OH from 1860-2100, Atmos. Chem. Phys., 12, 12021-12036, doi:10.5194/acp-12-12021-2012, 2012.

Krewski, D., Jerrett, M., Burnett, R. T., Ma, R., Hughes, E., Shi, Y., Turner, M. C., Pope, C. A., Thurston, G., Calle, E. E., Thun, M. J., Beckerman, B., DeLuca, P., Finkelstein, N., Ito, K., Moore, D. K., Newbold, K. B., Ramsay, T., Ross, Z., Shin, H., and Tempalski, B.: Extended follow-up and spatial analysis of the American Cancer Society study linking particulate air pollution and mortality, Health Effects Institute, Cambridge, MA, USA, 5-114, 2009.

Lamarque, J. F., Hess, P., Emmons, L., Buja, L., Washington, W., and Granier, C.: Tropospheric ozone evolution between 1890 and 1990, J. Geophys. Res., 110, D08304, doi:10.1029/2004jd005537, 2005.

Lamarque, J.-F., Bond, T. C., Eyring, V., Granier, C., Heil, A., Klimont, Z., Lee, D., Liousse, C., Mieville, A., Owen, B., Schultz, M. G., Shindell, D., Smith, S. J., Stehfest, E., Van Aardenne, J., Cooper, O. R., Kainuma, M., Mahowald, N., McConnell, J. R., Naik, V., Riahi, K., and van Vuuren, D. P.: Historical (1850-2000) gridded anthropogenic and biomass burning emissions of reactive gases and aerosols: methodology and application, Atmos. Chem. Phys., 10, 7017-7039, doi:10.5194/acp10-7017-2010, 2010.

Lamarque, J.-F., Shindell, D. T., Josse, B., Young, P. J., Cionni, I., Eyring, V., Bergmann, D., Cameron-Smith, P., Collins, W. J., Doherty, R., Dalsoren, S., Faluvegi, G., Folberth, G., Ghan, S. J., Horowitz, L. W., Lee, Y. H., MacKenzie, I. A., Nagashima, T., Naik, V., Plummer, D., Righi, M., Rumbold, S., Schulz, M., Skeie, R. B., Stevenson, D. S., Strode, S., Sudo, K., Szopa, S., Voulgarakis, A., and Zeng, G.: The Atmospheric Chemistry and Climate Model Intercomparison Project (ACCMIP): overview 
and description of models, simulations and climate diagnostics, Geosci. Model Dev. Discuss., 5, 2445-2502, doi:10.5194/gmdd5-2445-2012, 2012.

Lavanchy, V. M. H., Gäggeler, H. W., Schotterer, U., Schwikowski, M., and Baltensperger, U.: Historical record of carbonaceous particle concentrations from a European high-alpine glacier (Colle Gnifetti, Switzerland), J. Geophys. Res., 104, 21227-21236, doi:10.1029/1999jd900408, 1999.

Levy, J. I., Chemerynski, S. M., and Sarnat, J. A.: Ozone Exposure and Mortality: "An Empiric Bayes Metaregression Analysis", Epidemiology, 16, 458-468, doi:10.1097/01.ede.0000165820.08301.b3, 2005.

Levy, H., Schwarzkopf, M. D., Horowitz, L., Ramaswamy, V., and Findell, K. L.: Strong sensitivity of late 21 st century climate to projected changes in short-lived air pollutants, J. Geophys. Res., 113, D06102, doi:10.1029/2007JD009176, 2008.

Liao, H., Chen, W.-T., and Seinfeld, J. H.: Role of climate change in global predictions of future tropospheric ozone and aerosols, J. Geophys. Res., 111, D12304, doi:10.1029/2005jd006852, 2006.

Lin, M., Fiore, A. M., Horowitz, L. W., Cooper, O. R., Naik, V., Holloway, J., Johnson, B. J., Middlebrook, A. M., Oltmans, S. J., Pollack, I. B., Ryerson, T. B., Warner, J. X., Wiedinmyer, C., Wilson, J., and Wyman, B.: Transport of Asian ozone pollution into surface air over the western United States in spring, J. Geophys. Res., 117, D00V07, doi:10.1029/2011jd016961, 2012.

Liu, J., Mauzerall, D. L., Horowitz, L. W., Ginoux, P., and Fiore, A. M.: Evaluating inter-continental transport of fine aerosols: (1) Methodology, global aerosol distribution and optical depth, Atmos. Environ., 43, 4327-4338, doi:10.1016/j.atmosenv.2009.03.054, 2009a.

Liu, J., Mauzerall, D. L., and Horowitz, L. W.: Evaluating Inter-continental transport of fine aerosols: (2) Global Health Impacts, Atmos. Environ., 43, 4339-4347, doi:10.1016/j.atmosenv.2009.05.032, 2009b.

Marenco, A., Gouget, H., NÈdÈlec, P., PagÈs, J.-P., and Karcher, F.: Evidence of a long-term increase in tropospheric ozone from Pic du Midi data series: Consequences: Positive radiative forcing, J. Geophys. Res., 99, 16617-16632, doi:10.1029/94jd00021, 1994.

Marlon, J. R., Bartlein, P. J., Carcaillet, C., Gavin, D. G., Harrison, S. P., Higuera, P. E., Joos, F., Power, M. J., and Prentice, I. C.: Climate and human influences on global biomass burning over the past two millennia, Nature Geosci, 1, 697-702, 2008.

McConnell, J. R., Edwards, R., Kok, G. L., Flanner, M. G., Zender, C. S., Saltzman, E. S., Banta, J. R., Pasteris, D. R., Carter, M. M., and Kahl, J. D. W.: 20th-Century Industrial Black Carbon Emissions Altered Arctic Climate Forcing, Science, 317, 13811384, doi:10.1126/science.1144856, 2007.

Meinshausen, M., Smith, S., Calvin, K., Daniel, J., Kainuma, M., Lamarque, J. F., Matsumoto, K., Montzka, S., Raper, S., Riahi, K., Thomson, A., Velders, G., and van Vuuren, D. P.: The RCP greenhouse gas concentrations and their extensions from 1765 to 2300, Climatic Change, 109, 213-241, doi:10.1007/s10584-0110156-z, 2011.

Mickley, L. J., Jacob, D. J., and Rind, D.: Uncertainty in preindustrial abundance of tropospheric ozone: Implications for radiative forcing calculations, J. Geophys. Res., 106, 3389-3399, doi:10.1029/2000jd900594, 2001.

Mieville, A., Granier, C., Liousse, C., Guillaume, B., Mouillot, F., Lamarque, J. F., Grégoire, J. M., and Pétron, G.: Emissions of gases and particles from biomass burning during the 20th century using satellite data and an historical reconstruction, Atmos. Environ., 44, 1469-1477, doi:10.1016/j.atmosenv.2010.01.011, 2010.

Murazaki, K. and Hess, P.: How does climate change contribute to surface ozone change over the United States?, J. Geophys. Res., 111, D05301, doi:10.1029/2005jd005873, 2006.

Naik, V., Horowitz, L. W., Fiore, A. M., Mao, J., Aghedo, A., and Levy, H. I.: Preindustrial to present day impact of short-lived pollutant emissions on atmospheric composition and climate, J. Geophys. Res., in review, 2013.

Nakicenovic, N., Alcamo, J., Davis, G., de Vries, B., Fenhann, J., Gaffin, S., Kenneth Gregory, Grübler, A., Jung, T. Y., Kram, T., Rovere, E. L. L., Michaelis, L., Mori, S., Morita, T., Pepper, W., Pitcher, H., Price, L., Riahi, K., Roehrl, A., Rogner, H.-H., Sankovski, A., Schlesinger, M., Shukla, P., Smith, S., Swart, R., van Rooijen, S., Victor, N., and Zhou, D.: Special Report on Emissions Scenarios: A Special Report of Working Group III of the Intergovernmental Panel on Climate Change, Cambridge University Press, Cambridge, UK, 570, 2000.

Pope, C. A. and Dockery, D. W.: Health effects of fine particulate air pollution: lines that connect, J. Air Waste Manage. Assoc, 56, 709-742, 2006.

Pope, C. A., Burnett, R. T., Thun, M. J., Calle, E. E., Krewski, D., Ito, K., and Thurston, G. D.: Lung Cancer, Cardiopulmonary Mortality, and Long-term Exposure to Fine Particulate Air Pollution, J. Amer. Med. Assoc., 287, 1132-1141, doi:10.1001/jama.287.9.1132, 2002.

Prather, M. J., Holmes, C. D., and Hsu, J.: Reactive greenhouse gas scenarios: Systematic exploration of uncertainties and the role of atmospheric chemistry, Geophys. Res. Lett., 39, L09803, doi:10.1029/2012GL051440, 2012.

Ramaswamy, V., Boucher, O., Haigh, J., Hauglustaine, D., Haywood, J., Myhre, G., Nakajima, T., Shi, G. Y., Solomon, S., Betts, R., Charlson, R., Chuang, C., Daniel, J. S., Genio, A. D., Dorland, R. v., Feichter, J., Fuglestvedt, J., Forster, P. M. d. F., Ghan, S. J., Jones, A., Kiehl, J. T., Koch, D., Land, C., Lean, J., Lohmann, U., Minschwaner, K., Penner, J. E., Roberts, D. L., Rodhe, H., Roelofs, G. J., Rotstayn, L. D., Schneider, T. L., Schumann, U., Schwartz, S. E., Schwarzkopf, M. D., Shine, K. P., Smith, S., Stevenson, D. S., Stordal, F., Tegen, I., and Zhang, Y.: Radiative Forcing of Climate Change, in: Climate Change 2001: The Scientific Basis. Contribution of Working Group I to the Third Assessment Report of the Intergovernmental Panel on Climate Change, edited by: Houghton, J. T., Ding, Y., Griggs, D. J., Noguer, M., Linden, P. J. v. d., Dai, X., Maskell, K., and Johnson, C. A., Cambridge University Press, Cambridge, United Kingdom 881, 2001.

Richter, A., Burrows, J. P., Nusz, H., Granier, C., and Niemeier, U.: Increase in tropospheric nitrogen dioxide over China observed from space, Nature, 437, 129-132, doi:10.1038/nature04092, 2005.

Schultz, M. G., Heil, A., Hoelzemann, J. J., Spessa, A., Thonicke, K., Goldammer, J. G., Held, A. C., Pereira, J. M. C., and van het Bolscher, M.: Global wildland fire emissions from 1960 to 2000, Global Biogeochem. Cy., 22, GB2002, doi:10.1029/2007gb003031, 2008.

Shindell, D. T., Levy II, H., Schwarzkopf, M. D., Horowitz, L. W., Lamarque, J.-F., and Faluvegi, G.: Multimodel projections of climate change from short-lived emissions due to human activities, 
J. Geophys. Res., 113, D11109, doi:10.1029/2007JD009152, 2008.

Shindell, D. T., Faluvegi, G., Koch, D. M., Schmidt, G. A., Unger, N., and Bauer, S. E.: Improved attribution of climate forcing to emissions, Science, 326, 716-718, doi:10.1126/science.1174760, 2009.

Spivakovsky, C. M., Logan, J. A.,, Montzka, S. A., Balkanski, Y. J., Foreman-Fowler, M., Jones, D. B. A., Horowitz, L. W., Fusco, A. C., Brenninkmeijer, C. A. M., Prather, M. J., Wofsy, S. C., and McElroy, M. B.: Three-dimensonal climatological distribution of tropospheric OH: Update and evaluation, J. Geophys. Res., 105, 8931-8980, 2000.

Staffelbach, T., Neftel, A., Stauffer, B., and Jacob, D.: A record of the atmospheric methane sink from formaldehyde in polar ice cores, Nature, 349, 603-605, 1991.

Tagaris, E., Liao, K.-J., DeLucia, A. J., Deck, L., Amar, P., and Russell, A. G.: Potential Impact of Climate Change on Air PollutionRelated Human Health Effects, Environ. Sci. Technol., 43, 49794988, doi:10.1021/es803650w, 2009.

Tsigaridis, K., Krol, M., Dentener, F. J., Balkanski, Y., Lathière, J., Metzger, S., Hauglustaine, D. A., and Kanakidou, M.: Change in global aerosol composition since preindustrial times, Atmos. Chem. Phys., 6, 5143-5162, doi:10.5194/acp-6-5143-2006, 2006.

UNEP (United Nations Environment Programme) Nairobi, Kenya: United Nations Environment Programme and World Meteorological Organization, Opportunities to Limit Near-Term Climate Change: An Integrated Assessment of Black Carbon and Tropospheric Ozone and Its Precursors, 2011. van $\operatorname{der}$ A, R. J., Eskes, H. J., Boersma, K. F., van Noije, T. P. C., Van Roozendael, M., De Smedt, I., Peters, D. H. M. U., and Meijer, E. W.: Trends, seasonal variability and dominant $\mathrm{NO}_{\mathrm{x}}$ source derived from a ten year record of $\mathrm{NO}_{2}$ measured from space, J. Geophys. Res., 113, D04302, doi:10.1029/2007jd009021, 2008. van der Werf, G. R., Randerson, J. T., Giglio, L., Collatz, G. J., Kasibhatla, P. S., and Arellano Jr., A. F.: Interannual variability in global biomass burning emissions from 1997 to 2004, Atmos. Chem. Phys., 6, 3423-3441, doi:10.5194/acp-6-3423-2006, 2006.

Wang, Y. and Jacob, D. J.: Anthropogenic forcing on tropospheric ozone and $\mathrm{OH}$ since preindustrial times, J. Geophys. Res., 103, 31123-31135, doi:10.1029/1998jd100004, 1998.

West, J. J., Fiore, A. M., Horowitz, L. W., and Mauzerall, D. L.: Global health benefits of mitigating ozone pollution with methane emission controls, P. Natl. Acad. Sci., 103, 3988-3993, doi:10.1073/pnas.0600201103, 2006.

WHO: Global Burden of Disease (GBD) 2000: version 3 estimates, http://www.who.int/healthinfo/global_burden_disease/ estimates_regional_2000_v3/en/index.html (last access: August 2012), 2003.

Zeng, G. and Pyle, J. A.: Changes in tropospheric ozone between 2000 and 2100 modeled in a chemistry-climate model, Geophys. Res. Lett., 30, 1392, doi:10.1029/2002g1016708, 2003.

Zhang, L., Liu, H., and Zhang, N.: Impacts of internally and externally mixed anthropogenic sulfate and carbonaceous aerosols on East Asian climate, Acta Meteorologica Sinica, 25, 639-658, doi:10.1007/s13351-011-0508-7, 2011. 